\title{
Biofunctionalization of UHMWPE polymer and its application in Anterior Cruciate Ligament reconstruction
}

\author{
Sonia B. Wahed, Colin R. Dunstan, Philip A. Boughton, Andrew J. Ruys* \\ School of Biomedical Engineering, University of Sydney, Sydney NSW 2006, Australia. \\ Sonia.bintewahed@sydney.edu.au(S.B); \\ Colin.dunstan@sydney.edu.au. (C.R.D); \\ philip.boughton@sydney.edu.au (P.B); \\ Andrew.ruys@sydney.edu.au (A.J.R); \\ * Correspondence: Andrew.ruys@sydney.edu.au
}

\begin{abstract}
The selection of biomaterials for biomedical application is a significant challenge. In the last few decades, various bioabsorbable and stable biopolymers have been applied for use as biomedical devices in orthopedic applications. Ultra-high molecular weight polyethylene (UHMWPE) has been extensively used in medical implants, notably in the bearings of hip, knee, and other joint prostheses, owing to its biocompatibility and high wear resistance. For the ACL graft, synthetic UHMWPE is an ideal candidate due to its biocompatibility and its extremely high tensile strength. Despite the appeal of new advanced materials such as carbon fiber, poly-ether-ether ketone, and other load-bearing materials, UHMWPE remains a primary load-bearing candidate material for ACL reconstructions because of its extremely high strength, the simplicity of the fabrication process, its biocompatibility, and low friction. However, some significant problems are observed in UHMWPE based implants, such as wear debris, and oxidative degradation due to the generation of free radicals when exposed to irradiation with gamma rays for grafting or sterilization. Various innovative methodologies have been developed to resolve those problems and enhance the properties of UHMWPE. In this review, we will explore in detail the methods for surface functionalization of UHMWPE and will apply these findings to the case study of UHMWPE for Anterior Cruciate Ligament repair.
\end{abstract}

Keywords: Review; biomaterials; polyethylene; UHMWPE; ACL; Ligament; tendon; plasma treatment; surface modification; synthetic graft; bioactive glass.

\section{Introduction}

UHMWPE is an outstanding biopolymer with very high ultimate tensile strength, good biocompatibility, corrosion resistance, low water uptake, a low coefficient friction, and high abrasion resistance [1]. Such properties define UHMWPE's use in many development areas and in medicine and biology, including the manufacture of artificial joints and implants for surgery and orthopedics. All knee replacements and 85\% of hip replacements today use UHMWPE in their bearing surfaces, which represents over two million orthopedic implants a year [2]. Currently, UHMWPE is commercially fabricated under several brand names: Polymin SK (BASF, Germany), Polystone M (Roechling, Ger- many), Tivar (Quadrant, Belgium), Tecafine PE10 (Ensinger, Germany), Okulen 2000 (SP-Plast, Fin- land), GUR (Ticona, Germany), Chirulen (Poly-Hi Solidur, Germany) and by various companies, such as Goodfellow (United Kingdom) and Braskem (Brazilian Chemicals) [3]. Two key factors decide the quantity and consistency of implant-adhered cells: implant wettability (surface chemistry) and surface topography (surface roughness) [4-5].

Among other biomaterials, Ultra-high-molecular-weight-polyethylene (UHMWPE) fiber was selected in ligament and tendon reconstruction because it is the most durable biocompatible polymer 
known [6]. In addition, it, possesses excellent tensile strength, enough to support human load-bearing demands. Several articles have been published regarding the improvement of the surface of UHMWPE when its mechanical and tribological properties are modified. To improve the mechanical properties of UHMWPE, several materials have been used, including kaolin, carbon fiber, carbon nanotube, zirconium particles, hydroxyapatite, and alumina [7]. These materials can improve the surface hardness and abrasion resistance of the UHMWPE. The weakness of UHMWPE for medical applications is due to its low fusion point $\left(130^{\circ} \mathrm{C}-136^{\circ} \mathrm{C}\right)$, while limitations can be overcome by strengthening with composite materials including carbon fibers and nanotubes. Incorporation of Vitamin E can reduce the free radical formation by UHMWPE, when exposed to gamma radiation. Multiple methods have been utilized to modify the surface properties such as biocompatibility and wear resistance of UHMWPE [8].

Traditional ways of upgrading wear performance of the UHMWPE are by techniques such as gamma or electron beam radiation followed by thermal stabilization [9]. These techniques are accompanied by an increase in bulk mechanical properties, such as toughness, tensile strength, and fatigue performance, and wear resistance [10]. Surface modification techniques include chemical processes \& plasma treatment. Chemical surface modification of materials conducted have involved incorporation of Hydroxyapatite, Bio glass, Hyaluronan, polycaprolactone, multi-walled carbon nanotubes, Vitamin E, graphene oxide, DLC films, polydopamine into UHMWPE $[11,12,13]$.

Plasma treatment is currently one of the most technologically successful and safe method (doesn't need any corrosive reagents/solvent) for polymer material surface modification. Properties can be improved by surface treatment of UHMWPE with argon plasma, cold atmospheric plasma (CAP), plasma-assisted chemical vapor deposition (PACVD) and plasma immersion ion implantation (PIII) methods.

This review will focus on the surface properties of UHMWPE and their importance in anterior cruciate ligament reconstruction using UHMWPE, with a particular emphasis on chemical and plasma techniques to modify the surface properties.

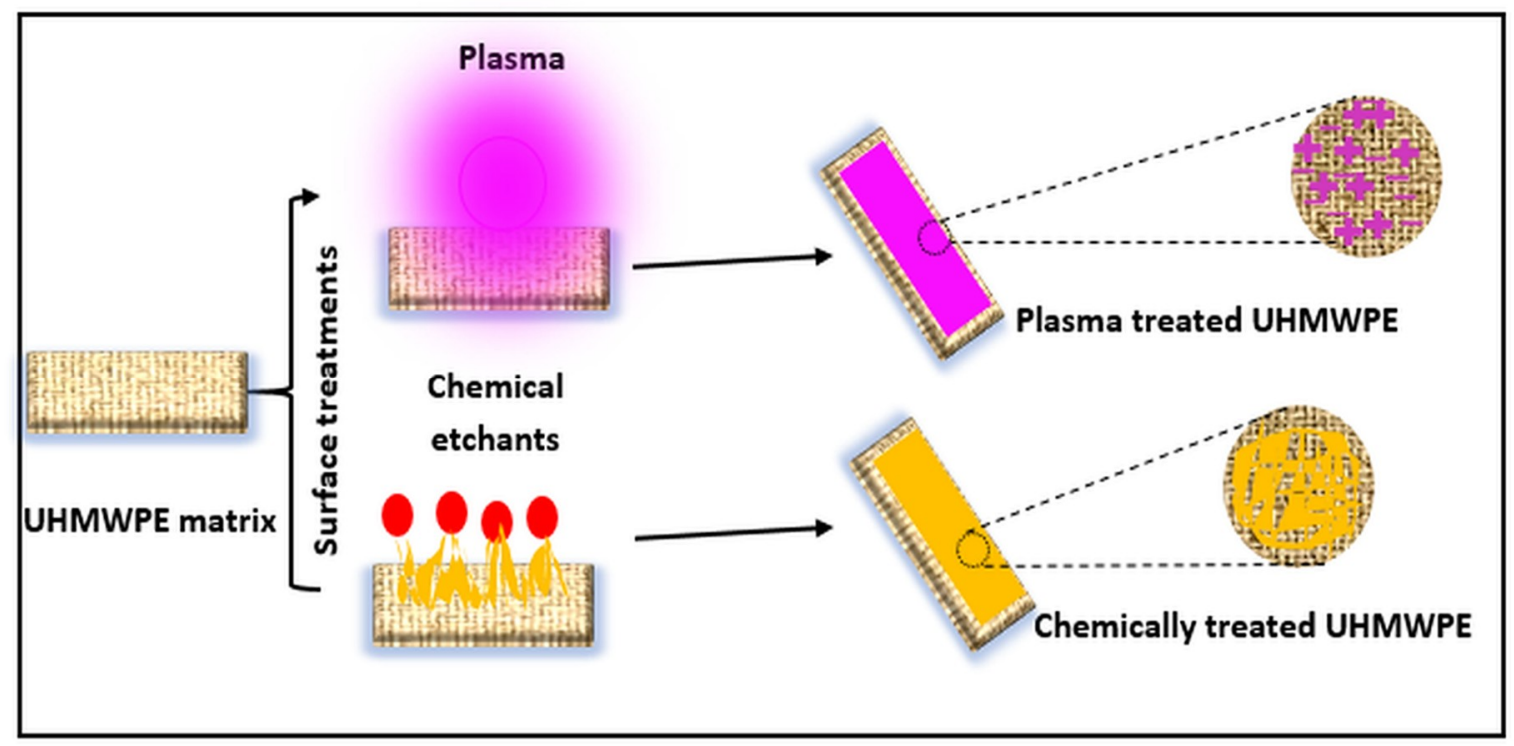

Fig 1: Two contrasting approaches for surface functionalization of UHMWPE: with plasma treatment (upper branch); or by incorporation of a different material (lower branch)

\section{UHMWPE:}


UHMWPE belongs to a subgroup of the thermoplastic polyethylene (PE) that are obtained from monomers of ethylene by a polymerization reaction. It is composed of extremely long polyethylene chains which effectively transfer load and provide a polymer backbone by reinforcing intermolecular interactions. The desired degree of polymerisation of UHMWPE is dependent on its end applications, the degree of polymerisation is observed in orthopaedic applications within a range of 71,000-214,000 with a molecular weight ranging from 2 to 6 million g / mole [14]. UHMWPE is also known as a high modulus PE or high-performance PE because of its toughness and good impact strength. Several monomer units attach during polymerization based on metallocene catalysts to make UHMWPE stronger compared to high-density polyethylene (HDPE). It also has extraordinary properties such as nontoxicity, high resistance to corrosive chemicals, and wear strength that makes it reliable for orthopaedic applications. UHMWPE is more abrasion and wear resistant than HDPE.

Table 1: Physical properties of high density polyethylene (HDPE) and ultrahigh molecular weight polyethylene (UHMWPE) [14]:

\begin{tabular}{|l|l|l|}
\hline Property & HDPE & UHMWPE \\
\hline Molecular weight $\left(10^{6} \mathrm{~g} / \mathrm{mol}\right)$ & $0.05-0.25$ & $3.5-7.5$ \\
\hline Tensile ultimate strength $(\mathrm{MPa})$ & $22-31$ & $39-48$ \\
\hline Tensile ultimate elongation $(\%)$ & $10-1200$ & $350-525$ \\
\hline
\end{tabular}

In 1962, Sir John Charnley introduced UHMWPE for biomedical use, and it was then applied as a joint surface load bearing material for hip and knee replacements. Hip and knee replacements are prosthetic joints that replace human joints affected by arthritis. The oxidation resistance of UHMWPE was improved by cross-linking, high-pressure crystallization, and introducing antioxidants.

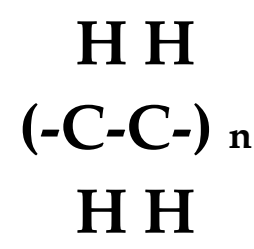

UHMWPE can also be used as woven, knitted, or nonwoven sheets to provide three-dimensional structures for cell ingrowth. UHMWPE fabrics can be produced by a gel spinning technique that allows for the parallel orientation of the fibres resulting in a high modulus of elasticity and strength. The market demand for medical-grade UHMWPE has risen tremendously from 60.9 kilotons (2015) to a projected 204.8 kilotons in (2024), according to a survey conducted by Grand view research [7]. Extensive use of UHMWPE in the medical field is due to its superior biocompatibility, chemical resistance, low wear volume, ultimate tensile strength, and low coefficient of friction. The sterilization of UHMWPE by ethylene oxide can be conducted without affecting the fibre properties. Different forms of UHMWPE used in biomedical engineering are:

1. UHMWPE fabric

2. UHMWPE sheet

3. UHMWPE rod

4. UHMWPE fibre

\section{Methodologies for surface modification of UHMWPE}

In ACL reconstruction, UHMWPE can be used in fabric or fiber form but in other biomedical sectors, it can be used as a sheet, rod, or powder form. UHMWPE has been used for shoulder replacements, hip arthroplasty, ankle replacements, other joint replacements due to its' high performance with low friction coefficient, high abrasion resistance, great aging resistance, and high impact strength properties. However, inertness and extreme hydrophobicity makes it inappropriate for this work [15]. Two specific types of functionalization method have been done to improve the properties of UHMWPE, which are described below: 


\subsection{Chemical treatment}

Silverstein et al. [16] have explored surface treatments using chromic acid, potassium permanganate, and hydrogen peroxide to reduce the smoothness of the polymer surface. These etchants were used to remove the weak outer layer of the polymer. A rough and oxidized UHMWPE surface was formed, with increased surface tension and enhanced wetting. The oxidized UHMWPE contains 6: 1 combination of ether and carbonyl bonds [16].

R. Sa.et al. [17] explained another surface modification of UHMWPE fiber with bioinspired polydopamine deposition and epoxy grafting to improve surface activity and adhesion properties of the material. In this experiment, UHMWPE was immersed in PDA (Polydopamine) solution, followed by dipping in the Ethylene glycol diglycidyl ether (EGDE) solution. This composite layer with adhered epoxy functional group improved interfacial strength as well as providing anchor points for further reactions[18]. Similar work was carried out by J. Hu et al. [19] to improve the surface activity and adhesion property of UHMWPE fibers. The amine-functionalized layer was created by immersing UHMWPE in a concentration of $2 \mathrm{~g} / \mathrm{L}$ polydopamine solution and then dried at $60^{\circ} \mathrm{C}$. The UHMWPE-PDA fibers were immersed again in a buffer solution containing $2 \mathrm{~g}$ of HMDA and dried at $60^{\circ} \mathrm{C}$ to get the final UHMWPE-PDA-HMDA fibers. Deposition of PDA and subsequent HMDA grafting had effectively developed a surface modification of UHMWPE fibers. The findings showed that the surface of UHMWPE-PDA fibers and UHMWPE-PDA-HMDA fibers was much rougher than that of pure fibers. Amine groups could react with epoxy groups of epoxy resins to improve the adhesion properties and interfacial shear strength of UHMWPE fibers [20].

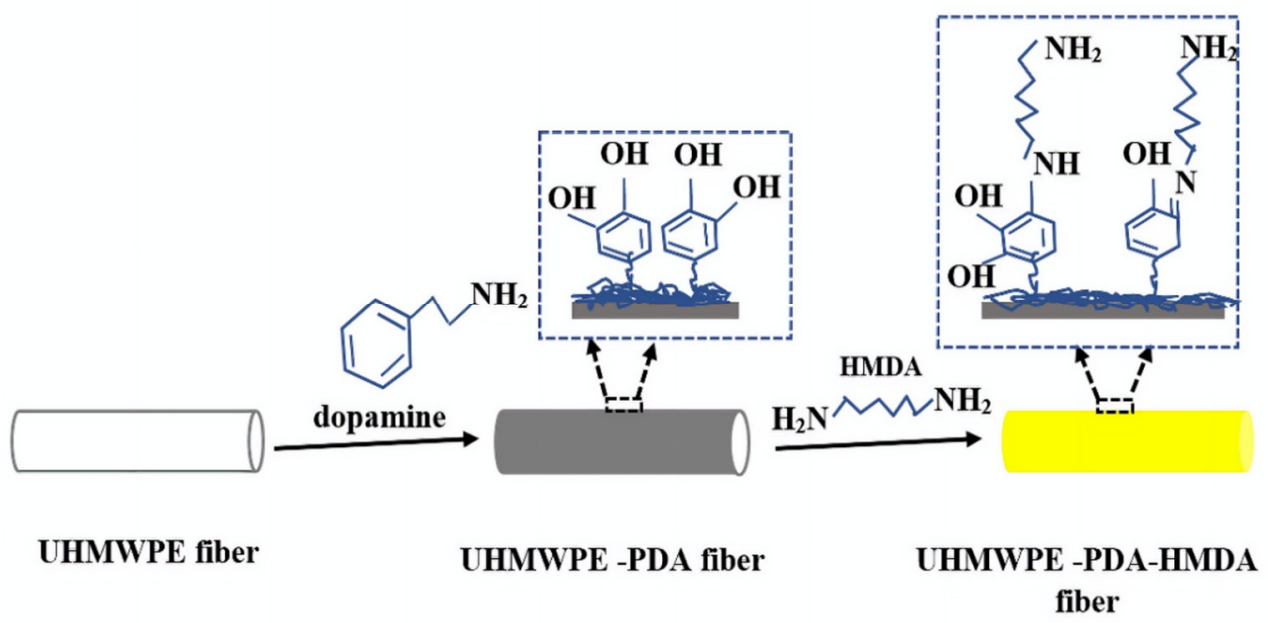

Fig 2: Surface functionalization of UHMWPE fibers with PDA \& HMDA (sourced from[20]).

James et al. from Colorado State University developed a UHMWPE -HA hyaluronan micro composite where a small portion of HA was covalently bonded into a porous preform of UHMWPE to act as articular cartilage and joint replacement materials. It was claimed that UHMWPE is hydrophobic, while articular cartilage is hydrophilic containing chondrocytes and extracellular matrix with proteoglycans [21]. Proteoglycans are large molecules with negatively charged side chains aggregates to the GAG core, HA. Higher HA concentration may impart viscoelastic gel-like properties to the synovial fluid and protects articular cartilage during sliding motion [22].

3.2 Surface modification of UHMWPE by different plasma (CAP,PACVD,ECR, DBD,PIII) and gamma irradiation methods

Plasma treatments modify the surface of the substrate without changing the mechanical properties of the substrate. Plasma modification is one of the most productive ways for the surface treatment of polymers as plasma treatment could selectively modify the physical and chemical properties of the surface of the polymers without affecting the original bulk characteristics of the polymer. 
Ionized precursor fragments are deposited on the substrate surface and result in the deposition of thin films on the substrate. Plasma treatments can provide the biocompatibility of the materials and the whole system [23,24], drug delivery devices [25,26], biofilms [27,28], next generation of nanobiointerfaces [29], anti-corrosion coatings, and corrosion with enhanced tribological properties, and can improve antibacterial properties $[30,31]$ etc. Compared to other surface modification treatments, Plasma surface modification offers shorter treatment time [32]. Plasma treatment is usually reliable, reproducible, non-line of sight, applicable to different sample geometries, as well as different materials such as metal, polymers, ceramics, and composites, etc [33]. Plasma processing can provide sterile surfaces and can be adopted easily by industrial purposes. Plasma activation has been successfully done for the improvement of the wettability of the polymer surfaces [34-36]. Surface properties of the polymers can be modified by using energetic photons, ions, or electric beams or laser treatment. Surface modifications of UHMWPE bring changes to surface topography and wettability of the sample [37].

Different plasma techniques and gamma irradiation for surface modification of UHMWPE have been described

below:

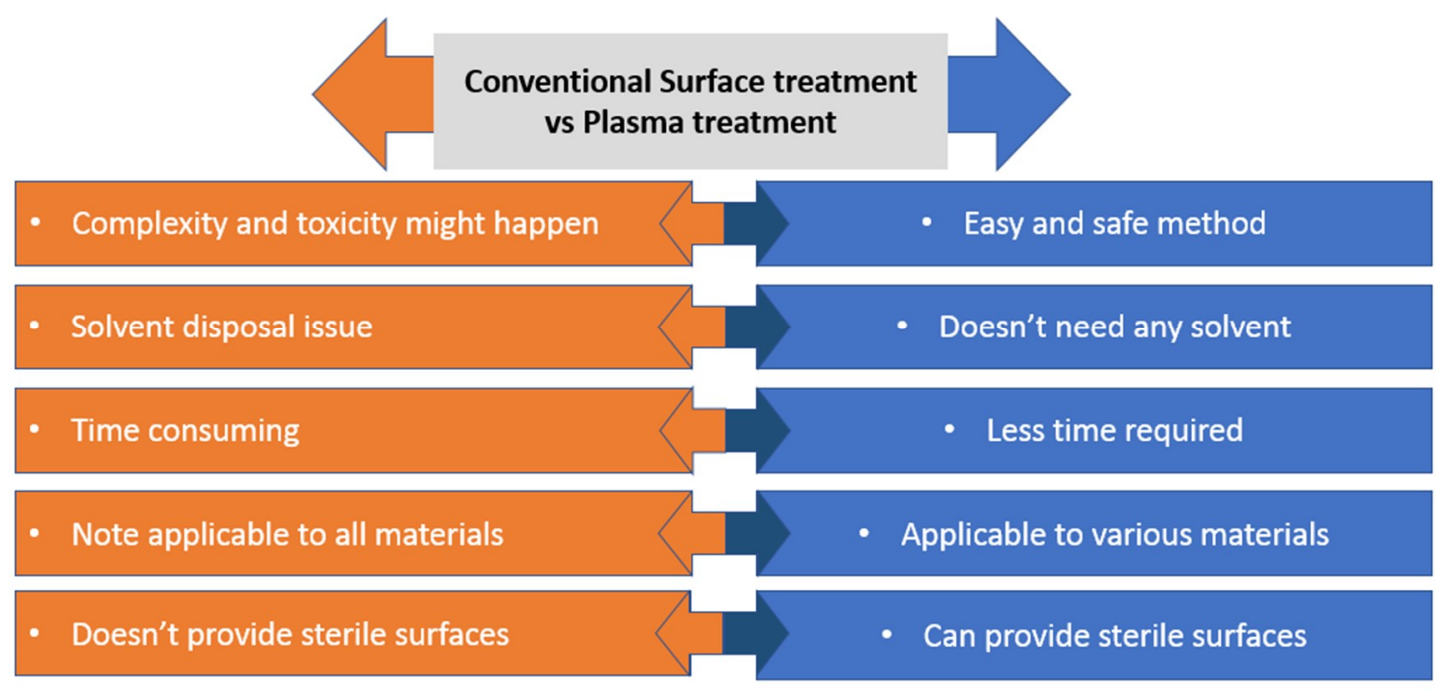

Fig 3: Comparison of surface treatments

\subsubsection{Cold atmospheric plasma (CAP):}

The functionalization of UHMWPE with cold atmospheric pressure gas plasma results in improved wear performance without affecting the cytocompatibility of the material. This is an inexpensive method that, has been used for modification of the surface properties of materials, and can provide a sterile surface environment. S.perni et al. [38] have determined that Cold atmospheric plasma functionalized materials show a greater level of cross-linking of the polyethylene chains [39]. Stiffness of the treated surface is increased due to the higher level of crosslinking. The longevity of replacement joints and discs is an important factor in determining the success of implant materials. In this treatment plasma was produced from helium mixed with different amounts of oxygen. The antimicrobial properties of cold gas plasma allow simultaneous wear performance enhancement and material sterilization [38,39,40]. In another study, Preddy et al. [7] illustrated that the surface functionalization of UHMWPE through the cold plasma method in the absence of air, can provide enhanced adhesion forces, and improved hydrophilicity. Similar functionalization of UHMWPE is achieved by using cold plasma where ionized gas produced from electrical discharge penetrating the material's surface at low pressure. Sterilization was achieved by the formation of reactive species, which inactivates the nucleophilic sites of microorganisms. M.M. Rodrigues et al. claimed that cold plasma is very efficient in sterilizing biomedical materials compared to other methods [41]. Interfacial adhesion of UHMWPE fiber-vinyl ester composites was modified by the oxygen and nitrogen plasma treatment of the UHMWPE fibers. Different types of chemical functional groups and micro pits were introduced when oxygen plasma was used. Nitrogen plasma treatment induced the formation of 
micro pits through etching but was not able induce the formation of chemical functional groups on the surface [42].

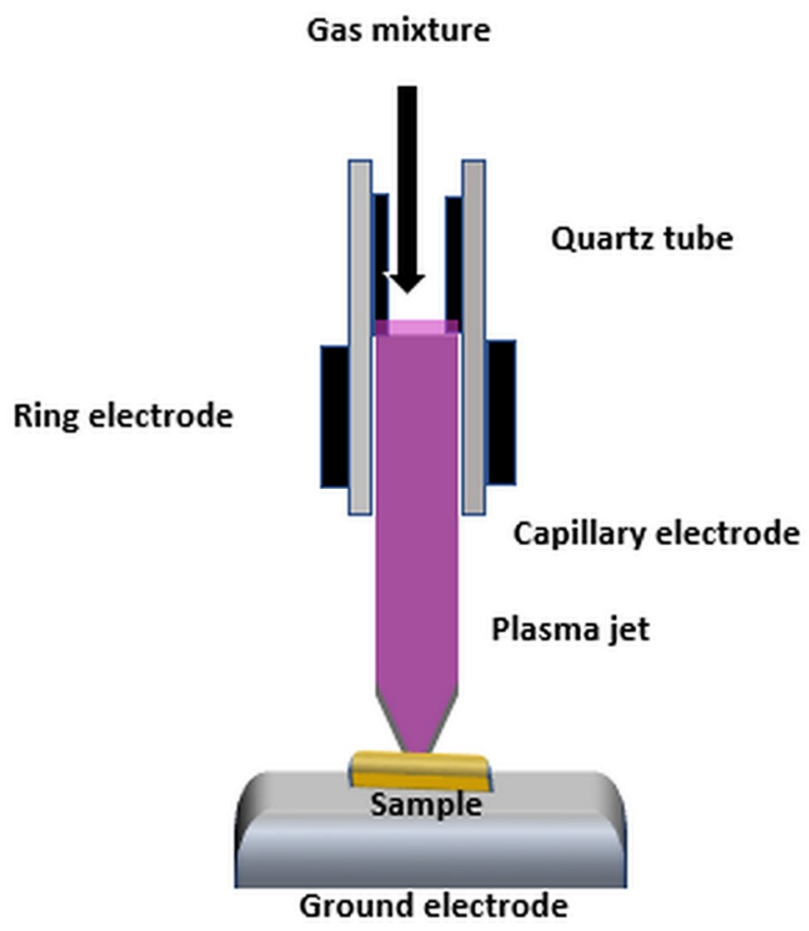

Fig 4: Schematic representation of a cold atmospheric gas plasma( Sourced from[39])

\subsubsection{Plasma-assisted chemical vapor deposition (PACVD):}

Among different plasma treatments, Struszczyk et al. have implemented a plasma-assisted chemical vapor deposition (PACVD) method for modification of the surface of UHMWPE composites [43]. The PACVD system consisted of two aluminum electrodes; the charged surface was positioned between the electrode. Two materials hexamethyldisiloxane (HMDSO) and tetradecafluorohexan to be deposited on the UHMWPE composite were injected into the gas mixture. The surface of composite UHMWPE was modified in a low-temperature plasma method with a radio frequency of $13.56 \mathrm{MHz}$ as the generator in an argon and air-gas mixture. The use of the PACVD method to deposit a polymer layer on composite UHMWPE can improve the main functionalities of the composite and provide new functional properties [44]. 


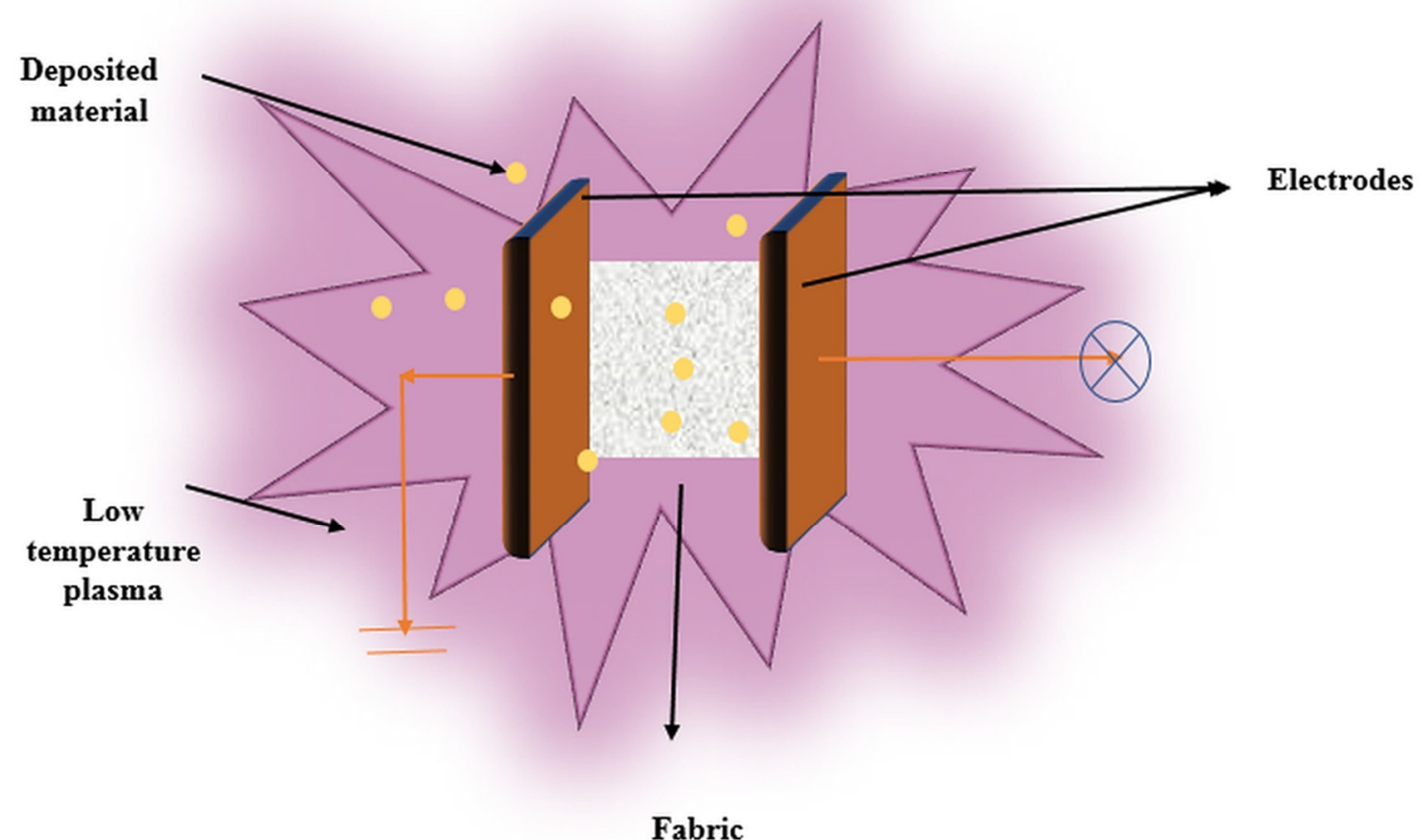

Fig 5 : PACVD system(Sourced from[44])

\subsubsection{Electron cyclotron resonance (ECR) plasma:}

S.E. More et al. [45] presented a surface modification technique of UHMWPE with microwaveassisted electron cyclotron resonance (ECR) plasma. A microwave power of $150 \mathrm{~W}$ and $2.45 \mathrm{GHz}$ was implanted through a quartz window into the ECR plasma chamber. Some unique properties of ECR, such as low-pressure range and a high degree of ionization, offer a good option for surface modifications of materials [46]. The low-pressure range can provide a sterile environment. This technique enhanced cellular adhesion through the generation of C-N/C-O related functional groups on the surface of the material [45]. Similar surface modification was carried out with ECR to improve the wettability, scratch resistance, and tribological properties of the UHMWPE [47]. 


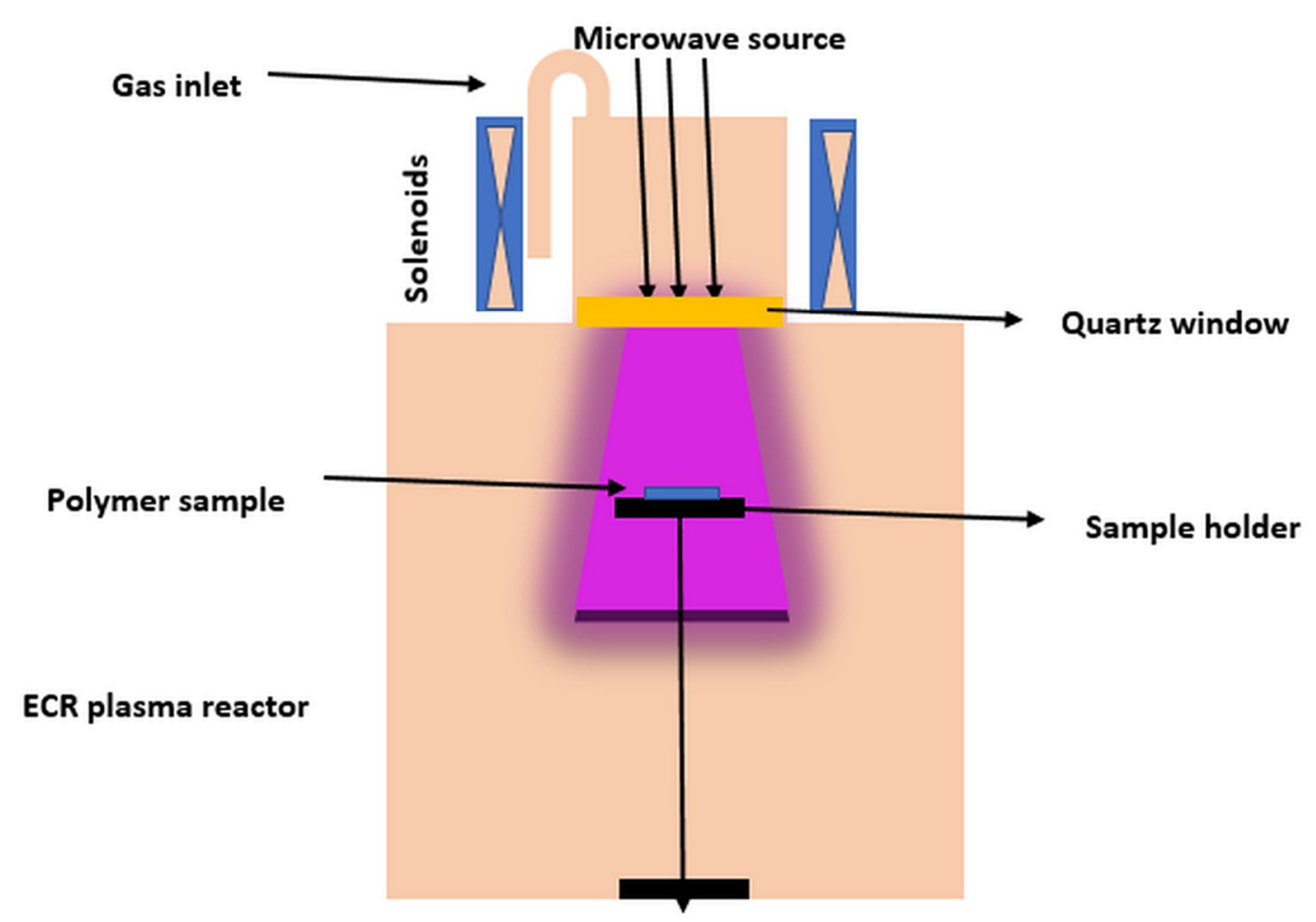

Fig 6: Schematic representation of ECR plasma(Sourced from[45])

\subsubsection{Dielectric barrier discharge (DBD) plasma:}

Y. Ren et al. [48] developed a new combined technique of dielectric barrier discharge (DBD) plasma and chitosan coatings to functionalise the surface of UHMWPE. A schematic of the DBD plasma treated apparatus is shown in the following figure. Plasma was generated between two plane parallel aluminium electrodes. Electrodes were $200 \mathrm{~cm}$ long and the upper electrode was covered with the insulating quartz glass layer (10 $\mathrm{mm}$ thick). The gap width between quartz glass sheet insulating and ground electrode was $2 \mathrm{~mm}$. The sample was placed between two electrodes and exposed to plasma at $200 \mathrm{~V}, 50 \mathrm{~Hz}$ from main power supply. The plasma treated sample was immersed in $0.7 \%$ $\mathrm{w} / \mathrm{v}$ concentration of chitosan solution and stirred for $10 \mathrm{~h}$ at the room temperature. Due to the plasma treatement hydroxyl, carbonyl, and carboxyl groups were introduced onto the surface of UHMWPE fiber surfaces and enhanced the wettability of the surfaces [49]. It was believed that amino groups of chitosan could be covalently bound to the surfaces of plasma treated UHMWPE by carboxyl groups to form amide bonds. Chitosan hydroxyl groups could also be covalently bonded to the surfaces by means of carboxyl groups to form ester bonds [48]. 


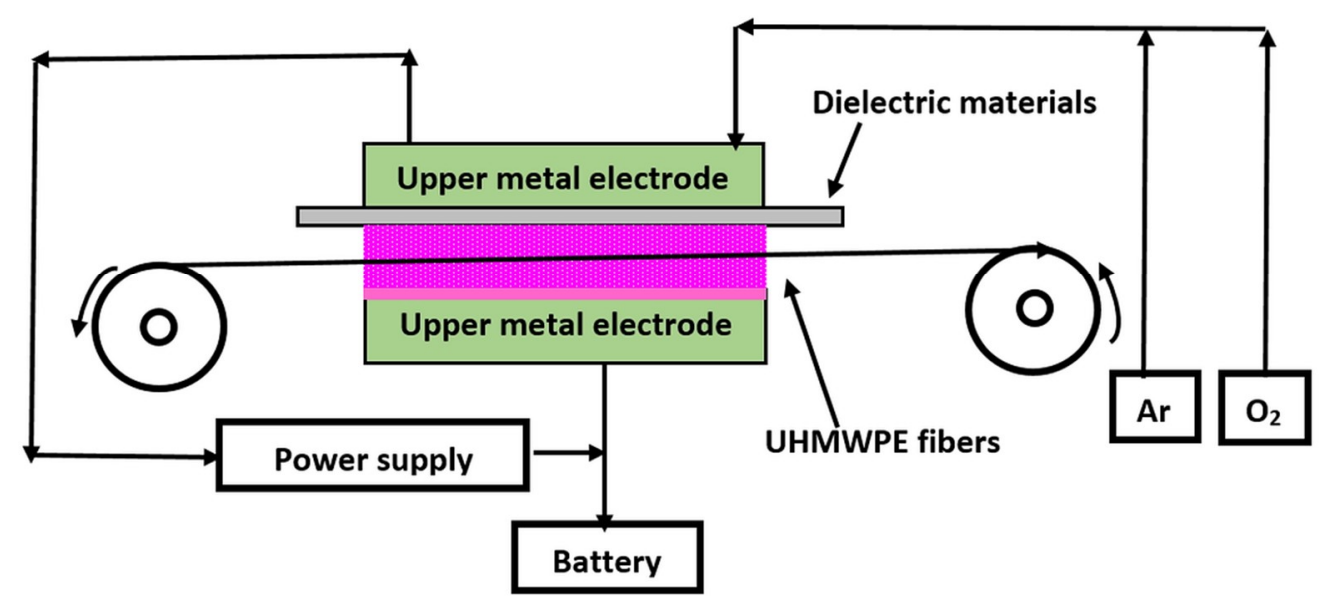

Fig 7: Schematic diagram of DBD plasma treatment system (Sourced from[48])

Lin et al. [47] outlined two surface modification methods of UHMWPE to identify their effects on surface properties of UHMWPE fibers. Three different types of epoxy resins- neat DGEBA, polyurethane-crosslinked DGEBA and BHHBP-DGEBA were examined as resin matrices for UHMWPE fiber-reinforced composites. Before each experiment, UHMWPE was cleaned in a polar and non-polar solvent and then dried in an oven at $60^{\circ} \mathrm{C}$. UHMWPE was plasma treated in four different times, and after the treatment, the fiber was exposed to air. In the chemical method, the UHMWPE fiber was plasma treated for 10 minutes and then immersed in dodecyl benzyl sulfonic acid mixture in different weight ratios and temperatures. It was reported that both experiments increased the degree of interfacial between fibers and matrices due to the formation of micro pits on the surface of materials [12].

\subsubsection{Plasma immersion ion implantation (PIII):}

Plasma immersion ion implantation, commonly expressed as $\mathrm{PIII}$ or $\mathrm{PI}^{3}$, is a unique plasma treatment technique initially developed as a revolutionary non-line of sight process. Instead of other conventional ion extraction methods, PIII works by absorbing a 3D shaped target in the ion acceleration scheme itself [50].In this method, the target substrate is immersed in plasma, biased to high voltages, and energetic ions are implanted from plasma to the substrate. Conrad et al. have developed the basic principles and applied them to treat specific 3D components and modified several materials using PIII [51].Nowadays, PIII can be used to deposit a carbon-based coating on the substrate rather than ion bombardment surface treatment. This treatment is carried out by injecting carbon-containing gas into the plasma formed in a background gas, which is referred to as plasma immersion ion implantation and deposition (PIII \& D) [52]. PIII treated diamond-like carbon films have been widely used in blood-contacting devices such as rotary blood pumps, artificial hearts, mechanical heart valves, and coronary stents [53].

In addition to the benefits of allowing the treatment of 3D objects, PIII also has high efficiency, can provide a large treatment area, batch processing capability, as well as small instrument footprint [52-54]. Typically the depth associated with plasma immersion ion implantation is $100 \mathrm{~nm}$ or less but can be enhanced by diffusion at elevated temperatures [55]. PIII has been widely applied for the modification of different kinds of materials such as semiconductor, display, and biomedical 
industries

[55].

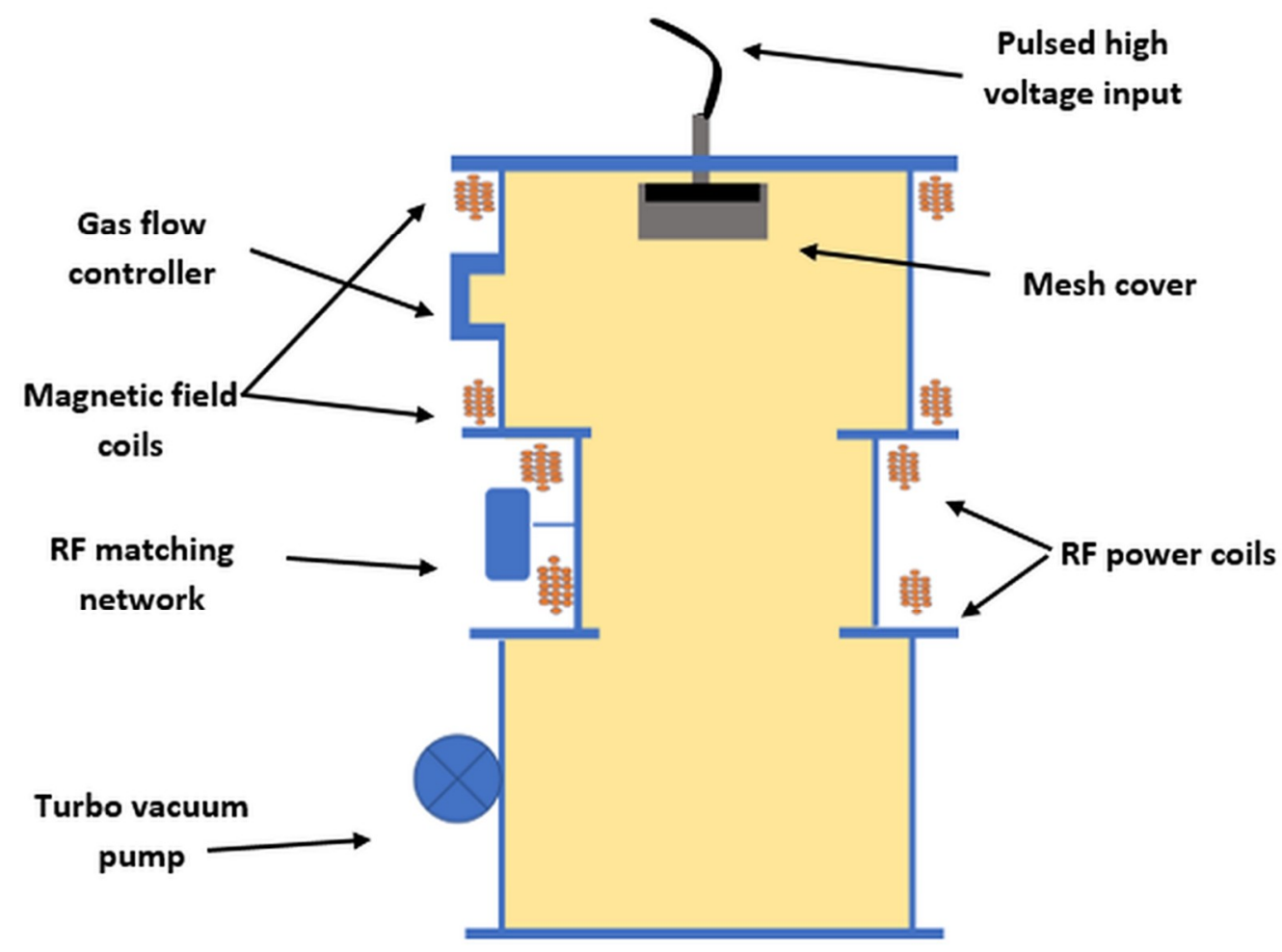

Fig 8: Schematic diagram of the PIII plasma chamber setup used for the treatment (Sourced from[56])

In the biomedical field, one of the applications of PIII is to enhance the blood compatibility of materials [57]. Different structures and compositions of Ti-O films were synthesized by PIII treatment. The structural difference was carried out by changing the oxygen flow rate into the vacuum chamber of the PIII device. This oxygen content can change the structure of the material from amorphous to mixed crystalline of anatase and rutile, and further becomes more rutile (stable form of $\mathrm{TiO}_{2}$ ). Increasing oxygen content enhanced the adhesive property of the platelet $[58,59]$. The mechanism of PIII treatment is illustrated below.

\subsubsection{Free radical generation:}

It has been noted that due to the introduction of cross-linking, chain scission, and injection of new elemental species, the PIII treated polymers display improved hardness and better wear resistance. Han and Lee et al. have been reported the altering of surface wettability of polystyrene after PIII treatment [60]. The formation of hydrophilic functional groups on the polymer surface has decreased the water contact angle of polystyrene. PIII is an up-and-coming surface modification technique for polymers, as large surface areas can be treated in a very fast and cost-effective manner [61].

PIII treatment can generate free radicals onto the surface of polymers that allows the immobilization of biomolecules. During the PIII treatment, the ion bombardment breaks down in polymers that create functional groups containing free radicals at the surface and also below the surface [54]. This is characterized by infra-red spectra by the appearance of absorption features in the regions of 1600 to $1650 \mathrm{~cm}^{-1}$ associated with the $\mathrm{C}=\mathrm{C}$ bond.

\subsubsection{Oxidation of the surface:}

Bilek and McKenzie demonstrated that Ar treatment causes nitrogen and oxygen incorporation into the polymer [54]. Due to the creation of active free radicals into the polymer by Ar plasma 
treatment, it can cause interaction with atmospheric oxygen and nitrogen. Infrared spectroscopy confirms that free radicals produced by the plasma process react with Oxygen, forming a variety of oxygen-containing species such as $\mathrm{C}-\mathrm{O}$, and $\mathrm{C}=\mathrm{O}$. The polarity of polymer comes from these chemical bonds and free radicals, which are polar. Longer Ar plasma treatment induces higher oxygen atom concentrations in the plasma exposed surface layers was explained by Ferencz et al [62].

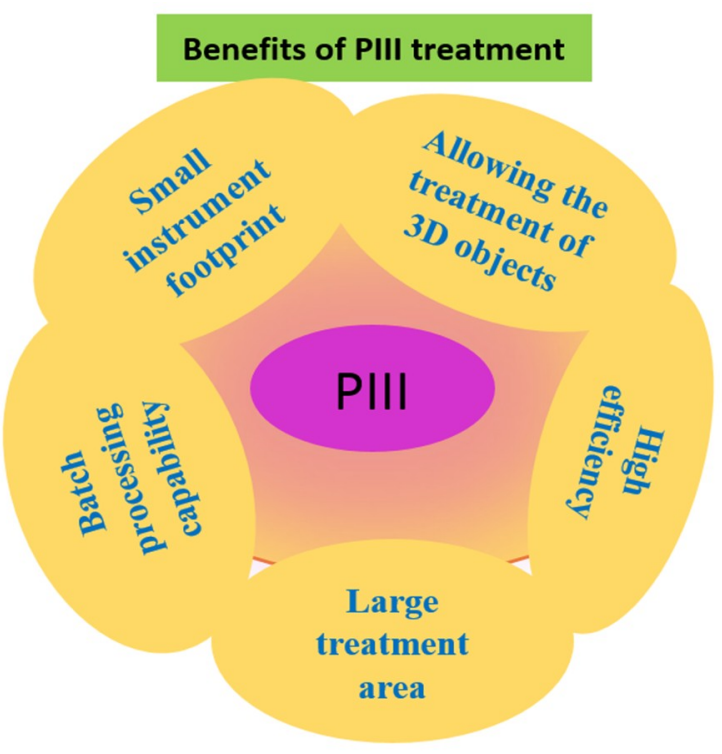

Fig 9: Benefits of PIII treatment

Surface modification of UHMWPE by plasma immersion ion implantation with nitrogen gas, showed promising results for improving surface mechanical properties such as hardness and elastic modulus of UHMWPE. Due to the formation of cross -like molecular microstructure , the surface of UHMWPE is expected to be predominanatly modified.Weak secondary bonds of the untreated material were replaced by strong covalent bonds at the cross-linked points, therefore decreased mobility of the molecular chain. As a result when subjected to applied force, modified UHMWPE showed higher hardness and elastic modulus than the untreated UHMWPE [63]. J. Chen et al. [64] have studied the surface modification of UHMWPE implanted by $80 \mathrm{keV} \mathrm{N} 2^{+}, \mathrm{C}_{3} \mathrm{H}_{8}{ }^{+}$, with a plasma density ranging from $1 \times 10^{14}$ to $5 \times 10^{15} \mathrm{ions} / \mathrm{cm}^{2}$. Surface modification was carried out by Elastic recoil detection (ERD) and X-ray photoelectron spectroscopy (XPS). ERD results detected the hydrogen deficient layer on the surface after the implantation, and XPS showed the existence of chemical bonds due to the injected nitrogen atoms, which helped in the crosslinking of the chemical groups [65]. When a polymeric material comes in contact with the charged particle, it loses its energy due to nuclear stopping(retarding force acting on the charged particle). Nuclear processing induces bond breakage or chain scission during irradiation [66]. Irradiation leads to dehydrogenation, which produced dangling bonds from the polymer chains. Thus, the dangling relationships may be connected with the implanted atoms or other harmful bonds, triggering the cross-linking process. Mechanical properties of the irradiated polymer, such as hardness and wear resistance, are generally correlated with the degree of cross-linking [67,68].

Table 2: Disadvantages of traditional surface functionalization methods [69]:

\begin{tabular}{|l|l|}
\hline \multicolumn{1}{|c|}{ Parameter } & \multicolumn{1}{c|}{ Effects } \\
\hline High temperature & Deteriorates the material [69-70] \\
\hline High-intensity energy & Oxidizes the material, increasing crystallinity, destroy the lifetime [71] \\
\hline UV radiation & Oxidative degradation of the material can damage the material [72-73] \\
\hline Chemical treatment & $\begin{array}{l}\text { Changes surface chemistry, the formation of toxic residues and by- } \\
\text { products, including carcinogens [74] }\end{array}$ \\
\hline
\end{tabular}




\subsubsection{Grafting on UHMWPE by gamma irradiation:}

J. wang et al. established a surface modification technique by introducing acrylamide groups through high energy ultraviolet initiated grafting reactions and thus was able to increase the tensile strength of UHMWPE [75]. Diphenyl ketone was used as an initiator for absorbing energy and producing double-free radicals for the process. The process of grafting was carried out by several steps; (i) initiation (ii) propagation (iii) transfer \& termination reactions [76]. Another similar surface modification was carried out on UHMWPE; the material was exposed to $\mathrm{y}$ radiation for improving bonding strength to PMMA (polymethyl methacrylate) cement. Two types of irradiation methods were adopted for this study: pre-irradiation and syn irradiation. Pre irradiation introduced a small coating of PMMA on the surface of UHMWPE but higher bonding strength than syn irradiation [77].

Jiangtao Hu et al. [72] studied a functionalization method for UHMWPE fabric by the radiationinduced graft polymerization reaction of $\gamma$-methacryloxypropyl trimethoxysilane (MAPS) and subsequent cohydrolysis of the graft chains (PMAPS) with tetra butyl titanate. Nanocrystalline Titania films generated on UHMWPE to improve thermal properties and UV resistances [72].Gamma irradiated UHMWPE exhibited a smaller area of accumulated cracks when reciprocating the loading movement compared to virgin UHMWPE. TOMITA ET AL. [27] reported that, incorporation of blended vitamin $\mathrm{E}$ into UHMWPE can reduce the crack formation and flaking like destruction of pure UHMWPE [78]. Vitamin E (alpha tocopherol) blending can generate different microstructures on the surface and subsurface of the UHMWPE.Vitamin E blending reduced crystallinity which is beneficial for increasing mechanical strength [79]. Another study revealed that, cross linking and vitamin E stabilization influenced microbial adhesions on UHMWPE. The combination of vitamin $\mathrm{E}$ stabilisation and crosslinking will give additional benefits in terms of microbial adhesion reduction [80-81].

To reduce the inertness of UHMWPE, vinyl triethoxysilane (VTEOS) containing hydrolyzable alkoxyl groups was grafted in situ onto UHMWPE by air plasma treatment. The graft proficiency controlled by reaction conditions, including time, RF power, and pressure in the reaction chamber. Incorporation of VTEOS into the UHMWPE enhanced wettability, high cell proliferation rate, and coarse structure without damaging the bulk structure of the material [82]. The functionalization of biomedical UHMWPE was achieved by plasma treatment, using atmospheric pressure plasma polymerization technology. The investigation done by $\mathrm{P}$. Cools et al. demonstrates the effect of plasma polymerization treatment on UHMWPE, where functionalization is carried out in the helium atmosphere at an ambient pressure to introduce methyl methacrylate into the PE samples to increase the adhesion between the polymer and the PMMA bone cement. The introduction of functional groups on the PE helps to anchor the polymer film to the substrate [83]. A similar study for the functionalization of UHMWPE is derived from the detailed investigation done by G. Aziz et al., explaining the post-irradiation grafting and UV polymerization onto UHMWPE surface. In this method of polymerization, He (Helium) has been used for activation and as a carrier gas for postirradiation and plasma polymerization process. The treatment is based on nitrogen-containing polymer coating on UHMWPE samples by different plasma and UV based techniques at different conditions [84].

\section{Biofunctionalization of UHMWPE by protein immobilization:}

Biomimetic materials for implants and microarray technology have been obstructed by the shortage of safe and simple methods to covalently combine bioactive molecules to the surface of a wide range of materials. Different types of wet chemical perspectives are described in the literature for linking biomolecules to surfaces [85]. S. Puertas et al. have been reported that the carboxyl group of polymers can be activated by carbodiimide chemistry [86]. N-hydroxysuccinimide (NHS) or sulfoNHS is also used to increase the coupling efficiency of material [87]. Salinization and plasma functionalization have been used for pretreatment of surfaces for the generation of reactive sites for covalent coupling on polymer surface [88,89]. Biofunctionalization of the pure base material is carried out by the attachment of bioactive proteins to surfaces. Secure attachment is required sometimes because many applications may require the protein to remain stable under hostile 
environmental conditions such as the flow of blood or washing with strong detergents or buffers [90]. Additionally, The optimal device performance is dependent on dense surface coverage and long term retention of the proteins conformation [91]. Surface modification of polymer for protein attachment can be done in physical or chemical ways such as attachment of linker molecules through active groups [92,93] UV treatment, plasma treatment $[94,95,96,97,98]$ and ion beam implantation $[99,100,101,102]$.

\subsection{Protein immobilization by chemical methods:}

Surface modification schemes are essential to functionalize the surface interfaces of materials. Poly DPA has been cross-linked or coated on materials to modify the surface chemistry of materials [17]. Surface modification and protein immobilization on UHMWPE polymer were carried out by dopamine self-polymerization and Schiff base reaction mechanism. In this method, 5\% UHMWPE and liquid paraffin were melted and mixed in a batch mixer at a temperature of $200^{\circ} \mathrm{C}$ for 20 minutes. The mixture was compressed to get a homogenous film. Polyester/cotton blended fabric was inserted between the UHMWPE/LP film and vulcanized at a specific condition so that the UHMWPE/LP solution became immersed in the material. The composite membrane was functionalized with a

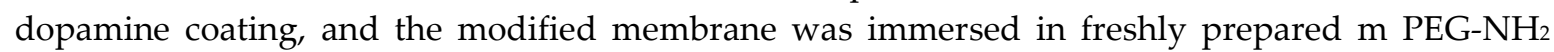
solution with a pH 10 at room temperature for 24 hours [19]. Dopamine layer introduced the hydrophilicity of the composite membrane, and $\mathrm{m}$ PEG-NH 2 modified the antifouling properties of the material.

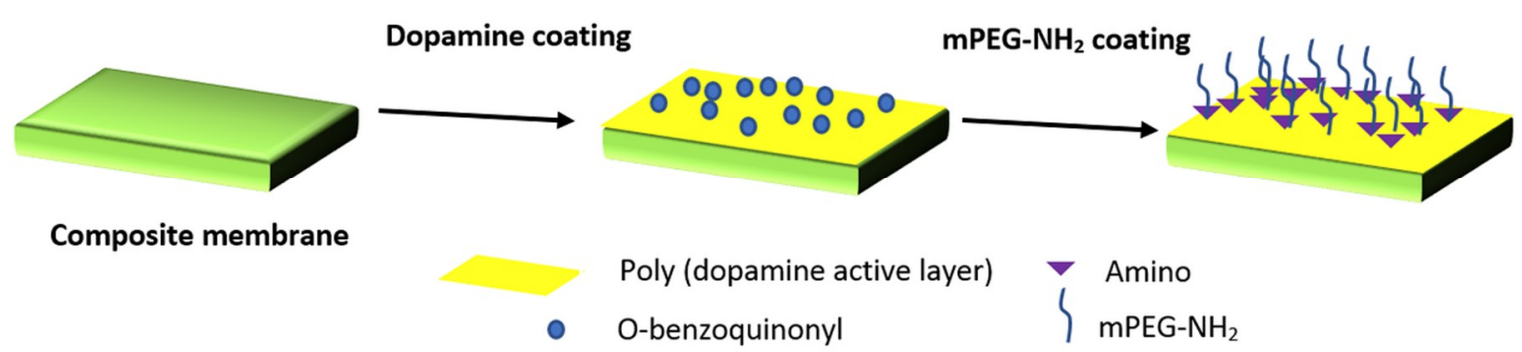

Fig 10: Dopamine self polymerization on composite membranes and subsequent $\mathrm{m}$ PEG-NH immobilization(Sourced from[19]).

Similar work conducted by J.H Jiang et al. [15] biofunctionalized UHMWPE with a polydopamine solution based on self polymerization reactions. Due to the coupling reaction between heparin and reactive polydopamine layer, heparin was immobilized covalently onto the UHMWPE surface [15].

\subsection{Protein immobilization by Plasma methods:}

Radiation damage of polymers through UV treatment, plasma treatment, and ion beam implantation can provide protein binding on polymers by strong binding, especially covalent binding without the specific linkers' groups.

Biofunctionalization of UHMWPE polymer was done by plasma treatment for adhesion improvement. A dielectric barrier discharge in $\mathrm{Ar}, \mathrm{He} / \mathrm{O}_{2}, \mathrm{He}, \mathrm{N}_{2}$ or $\mathrm{O}_{2}$ at atmospheric pressure was used for the continuous plasma treatment of UHMWPE fibers [103]. In terms of studies related to the biomedical application of plasma-treated UHMWPE, M.M. Rodrigues et al. demonstrated that the surface treatment of UHMWPE by cold plasma technique has significant effects on the proliferation of cells and improved the inertness of UHMWPE surface to a level comparable to commercially available cell culture materials. Widmer and Spencer treated UHMWPE with oxygen plasma to increase its hydrophilicity for getting faster and better protein adsorption. A wide range of work has focused on improving the longevity of joint implants used in human bod 
ies, as the biomedical implant contributes to wear debris when exposed to acts of human blood serum triggering the release of wear particles. In this work, a dense boundary layer of Human serum albumin (HSA) proteins on PE surface can enhance boundary lubrication and reduce $50 \%$ of dynamic friction as well as reduction of static frition in hip implants [104].

J. Bockova et al. [105] recently reported the use of air plasma to functionalize the surface of UHMWPE with collagen coating. This functionalization was achieved in two ways. Firstly, the acrylic acid was used to increase the hydrophilicity of the material and secondly with itaconic acid.Itaconic acid was used as an alternative to acrylic acid, and showed better biofunctionalization of UHMWPE, compared to acrylic acid. Collagen immobilization on the UHMWPE surface was carried out by a carbodiimide/hydroxysuccinimide cross-linking system [105].

The biofunctionalization of UHMWPE was derived from the detailed studies conducted by J. P. et al. explaining two methods for plasma treatment of an UHMWPE substrate. In this method of functionalization, Ar, and nitrogen PIII treatment with high electrical pulses was used to modify the surface of UHMWPE to provide improved hydrophilicity and interactions with proteins. The best performance was achieved by plasma immersion ion implantation using nitrogen gas [106]. Another similar approach has been made to functionalize the surface of UHMWPE by PIII treatment to improve the wettability of the surface. Horseradish peroxide (HRP) was immobilized on plasmatreated plasticized and unplasticized PVC and UHMWPE. Plasma immersion ion implantation (PIII) was conducted in nitrogen plasma with a radio frequency of $13.56 \mathrm{MHz}$. At different time frames. Different types of low molecular weight additives (plasticizer, solvent, adsorbed molecules on the surface) have been utilized on the surface to facilitate the protein immobilization. Small molecular additives held the protein molecules and helped to attach the protein on to the surface of the polymer [107].

a.

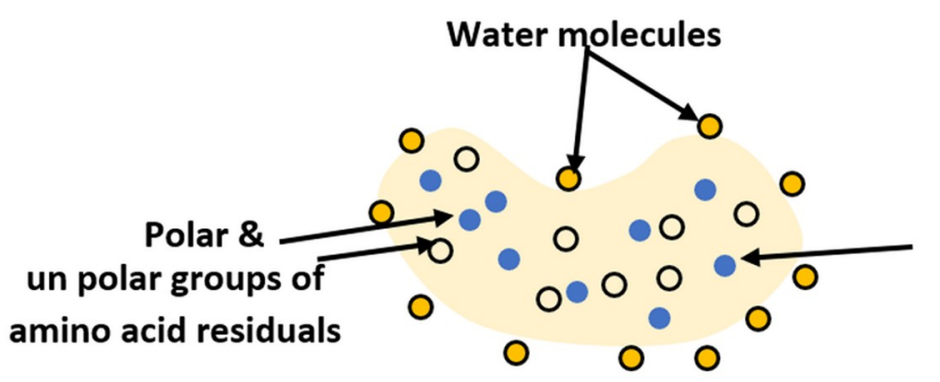

Protein molecule with polar \& non polar groups in water

b.

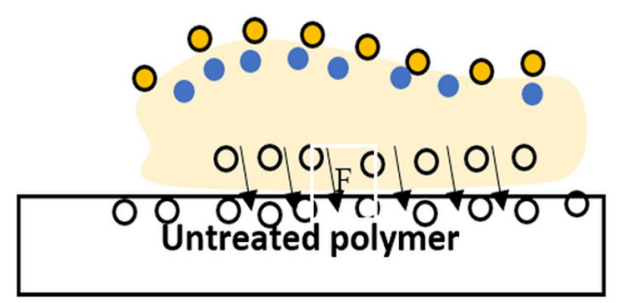




\section{C.}

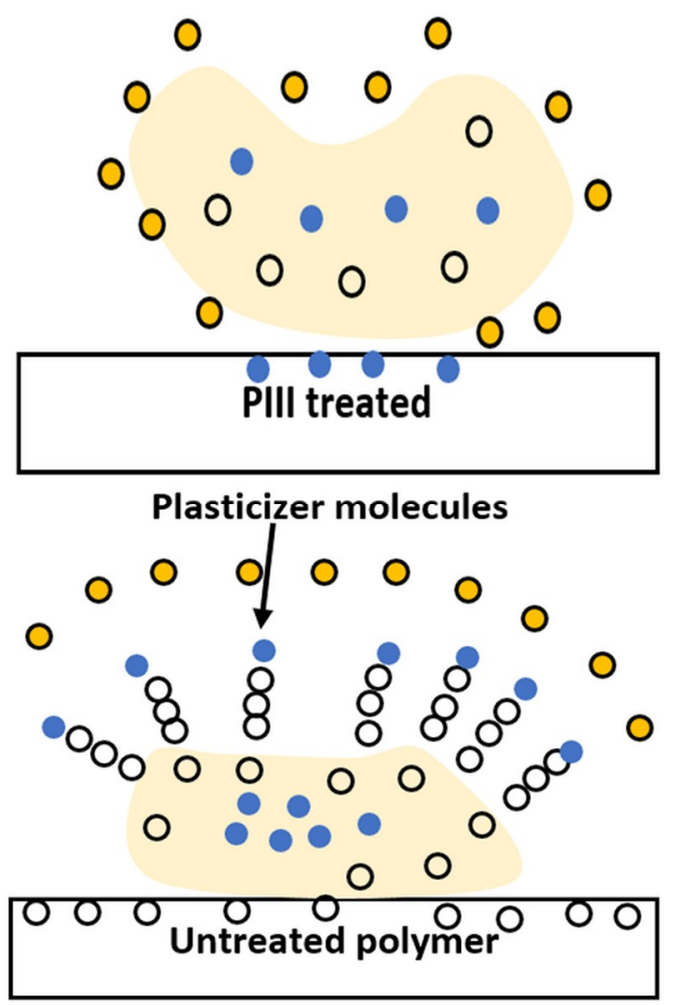

Fig 11: (a) The protein molecule in water (buffer) is surrounded by water molecules in order to provide polar interactions with the environment with polar groups on the external side. (b) the protein molecule spreads on untreated (nonpolar) polymer and is surrounded by water molecules such that the protein conformation is with polar groups (b) against water molecules and with nonpolar groups toward polymer surfaces $(\mathrm{O})$. (c) Molecule protein is covalently bonded to polymer treated with PIII. (d) The protein molecule falls on untreated (nonpolar) plasticized polymer, and the plasticizer and water molecules surround it (Sourced from [91]).

A similar type of biofunctionalization was reported by Alexey V. Kondyurin et al., explaining the mechanism of covalently attached Horseradish peroxide on the surface of UHMWPE. Gan et al. reported that energetic ions extracted from inductively coupled nitrogen plasma are used to modify the surface properties of UHMWPE [107]. The formation of the carbonized surface layer due to the oxidation of the ion damaged surface was claimed to account for protein binding on UHMWPE [106]. Among various methods, ion beam implantation and it's variant plasma immersion ion implantation has been used successfully for the covalent attachment of proteins on polymer surfaces [108].

\section{Selection of UHMWPE for ACL graft reconstruction:}

The knee joint is complex and is actually composed of three separate joints: the tibiofemoral, patellofemoral, and the proximal tibiofibular joints. The knee joint most commonly referred to is the tibiofemoral joint. These knee joints are stabilized by several ligaments, including the anterior cruciate ligament (ACL), the posterior cruciate ligament (PCL), the medial collateral ligament (MCL), and the lateral collateral ligament (LCL). Ligaments are made of bands of collagenous connective tissue. These paralleled collagen bundles are linkd to each other by crosslinking. Ligaments contain two-thirds water and one-third solid. Collagen is the major component of the ligament with 5 types prominent collagen type I, III, VI, XI, and XIV. The majority (90\%) of the collagen in ligaments is type I and which is responsible for its tensile strength. To maintain mechanical and biological stability of ligaments, related organ systems, as well as the bone, play a vital role. M. Laflamme reported that the type of material,and it's particle size, are important factors regarding synthetic ligament graft selection [109]. UHMWPE fibers are commonly used in synthetic ligament implants due to their 
excellent tensile strength and elastic modulus. Mechanical properties of several materials used for ACL regeneration have been presented in the following table:

Table 3: Mechanical properties of materials for synthetic grafts compared to normal ACL [110]

\begin{tabular}{|l|c|c|}
\hline Grafts & $\begin{array}{l}\text { Ultimate tensile } \\
\text { strength(N) }\end{array}$ & Stiffness(N/mm) \\
\hline Human ACL & 1730 & 242 \\
\hline Human hamstring graft & 3790 & 776 \\
\hline The human patellar tendon graft & & 685 \\
\hline Carbon fibers & 660 & $230 \times 10^{9}$ \\
\hline Gore-Tex prosthesis & 5300 & 322 \\
\hline Dacron & 3631 & 420 \\
\hline Twisted silk matrix & 2337 & 354 \\
\hline Parallel silk matrix & 1740 & 2214 \\
\hline KLAD & 280 & 1500 \\
\hline Trevira & 68.3 & 2000 \\
\hline Leeds-Keio & 270 & \\
\hline Braided PLGA & 907 & \\
\hline PLLA fiber & 175 & 115 \\
\hline UHMWPE fabric & 52570 & \\
\hline
\end{tabular}

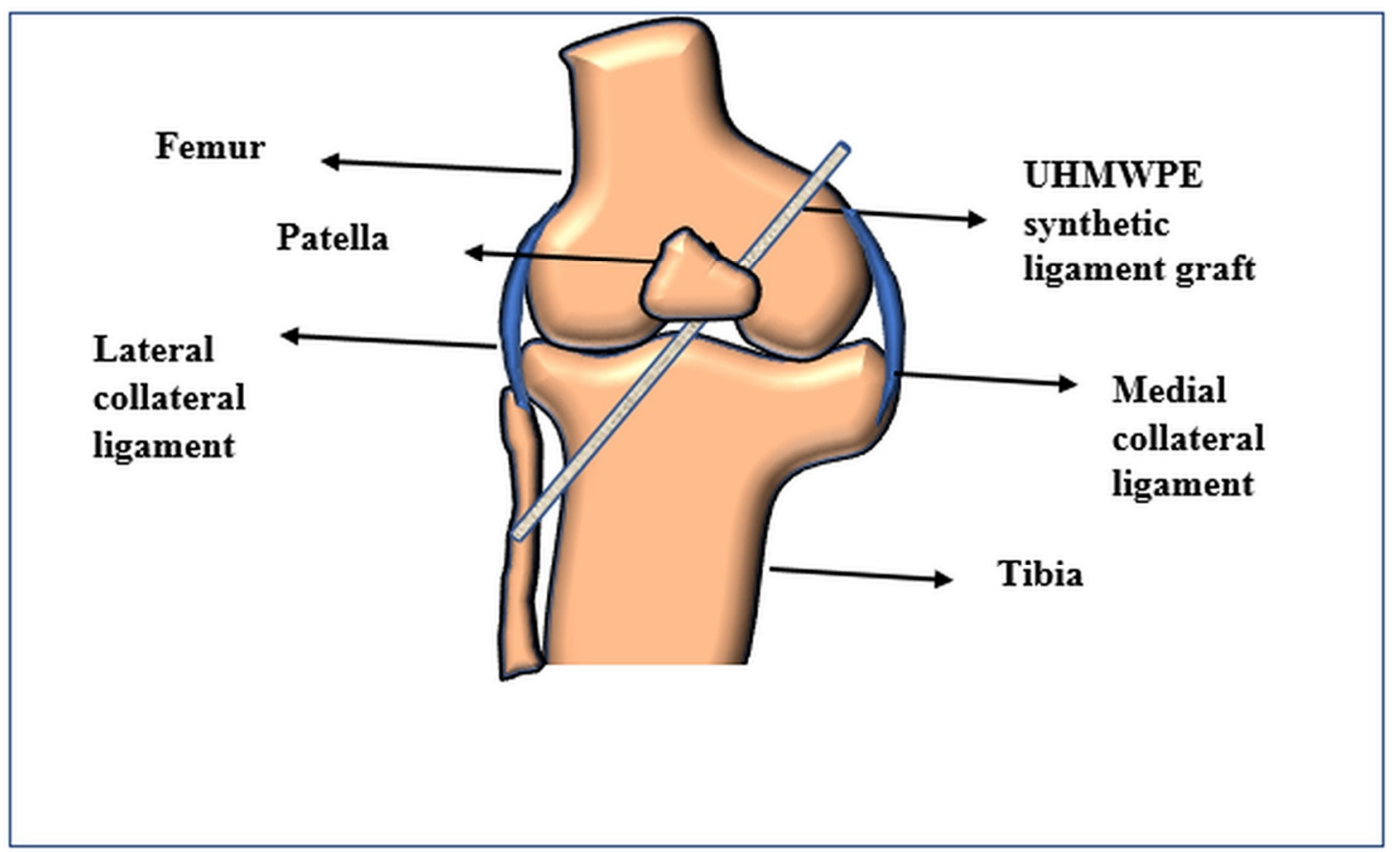

Fig 12: ACL reconstruction with UHMWPE synthetic graft

Wim van Overen reported[111] on thrombogenicity testing of UHMWPE compared to ePTFE and PET fibers for vascular applications. Hemobile is a method used to detect the damage of blood components and activation of platelets throughout the material/device. Hemobile was used for testing vascularity of UHMWPE, ePTFE and PET fiber. Due to lower hemolysis and low activation of 
the inflammatory responses, UHMWPE showed better hemocompatibility than ePTFE and PET fibers [111].

A. Hunter et al. [112] reported on attachment, and proliferation of a variety of cell types on UHMWPE for orthopedic implantation. Cell multiplication was counted with tritiated thymidine assay. Radioactively labelled thymidine (tritium) is used to measure lymphocyte proliferation by incorporating ${ }^{3} \mathrm{H}$ thymidine into the dividing cell's DNA. A component Vinculin, a cell focal adhesion plaque, was labeled by indirect immunofluorescence to assess the attachment of cells [113]. Fibroblasts and osteoblasts cultured directly on UHMWPE were tested by determining the mean number of adhesion plaques using an image analysis system. Fibroblasts attached well on UHMWPE fabric. High tensile strength, bio-inertness, and fibroblast adhesion makes it appropriate for ACL reconstruction [114].

Several materials has been developed that can be used for the reinforcement of matrix to modify the properties of UHMWPE, utilized for its application in ACL reconstruction.

\subsection{Common biomaterials for UHMWPE graft modification:}

Surface modification plays a major role in helping osteogenesis and bone anchorage of synthetic grafts [115]. Chitosan is a naturally derived polysaccharide that has been used for the modification of synthetic grafts $[116,117]$. Chitosan-Hyaluronic is a composite that promotes new bone formation at the graft bone interface $[118,119]$. Because of its porosity, biodegradability, biocompatibility, antiinfective activity, and ability to accelerate wound healing [120-121]. C. Vaquette et al. [122] reported that polystyrene sodium sulfonate as surface modification could improve the osteointegration of a synthetic graft [123].Bioactive glass stimulates angiogenic growth factors [124]. Bioactive glasses have unique compositional ranges of dense amorphous calcium sodium phosphosilicate (CSPS) that develop strong chemical bonds with the collagen of living tissues $[125,126]$. The composition of $45 \mathrm{~S} 5$ Bioglass is $45 \% \mathrm{SiO}_{2}, 24.5 \% \mathrm{CaO}, 24.5 \% \mathrm{Na}_{2} \mathrm{O}$, and $6 \% \mathrm{P}_{2} \mathrm{O}_{5}$ [127].Bioactive glasses dissolve slowly in a simulated body fluid (SBF) with some reactions taking place on the surface of the glass [128]. These reactions include: (i) Ions release due to the ion exchange between the solution and surface of the glass, but other components of the glass remain intact [129] (ii) $\mathrm{H}^{+}$ions attack the silica network and as a result $\mathrm{Si}-\mathrm{O}-\mathrm{Si}$ bonds break down, and new $\mathrm{Si}-\mathrm{OH}$ and $\mathrm{Si}(\mathrm{OH})_{4}$ groups are formed at the surface of the glass; (iii) A soluble porous silica-rich layer forms on the surface of the glass due to condensation and re-polymerization; (iv) A calcium phosphate-rich layer forms on the Si-rich layer due to the migration of $\mathrm{Ca}^{2+}$ and $(\mathrm{PO} 4)^{3-}$ ions; and (v) A polycrystalline apatite layer forms on the surface of the bioglass.Collagen fibers can attach to the surface of the bioactive glass. The transparent silica-rich layer induces precipitation of hydroxyapatite like (HCA) layer. Interactions between bioglass and collagen fibers occur and get stronger when HCA precipitation increases [130].

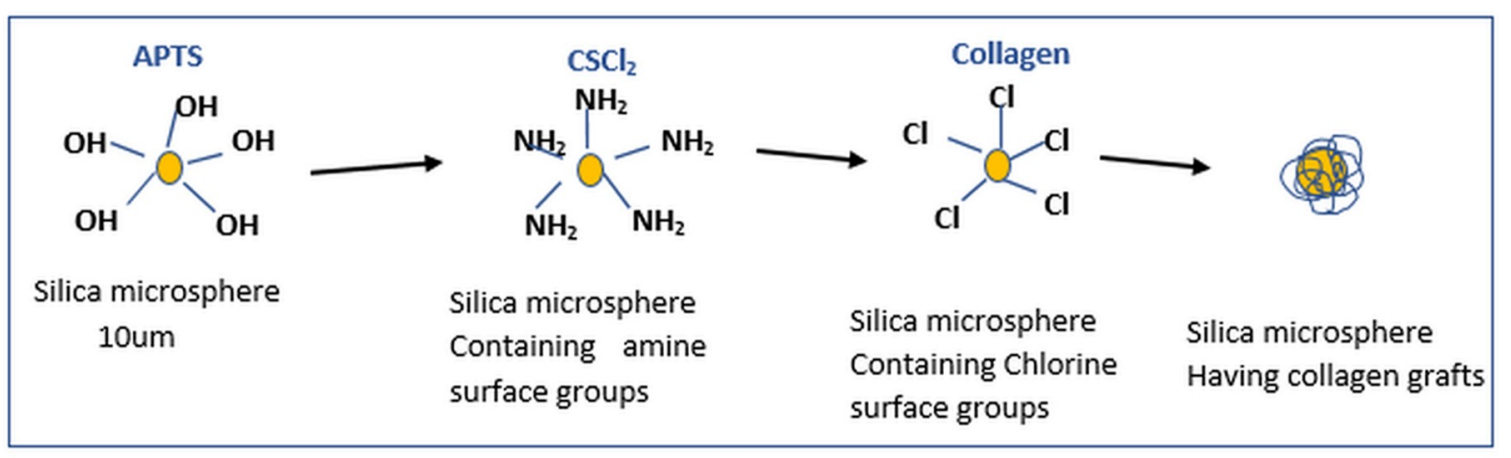

Fig 13: Bioactivity of Bioglass [125]

Bioglass coatings on polymer scaffolds made of foams, meshes, or fibrous bodies can be made by slurry dipping or electrophoretic deposition. Electrophoretic deposition delivers a homogenous and stable coating of Bioglass nanoparticles on the surface of polymeric composites. The electrophoretic deposition may cause blocking of interconnected pores; thus, slurry dipping has more 
advantages like uniform distribution of particles [115].Bioglass coatings on suture material are made by placing the polymer material into the Bioglass powder plate and applying pressure and heat for a period. In this technique, a uniform layer of Bioglass can be applied to a polymer surface [131]. A Bioglass coating improves the structural integrity of the composite by controlling the biodegradation rate and protecting it from some degradation.

J.J [131] reported that a different silver doped bioactive glass powder was applied to resorbable and non-resorbable vicryl polymer sutures to improve its microbial activity, bioactivity, and bactericidal activities [132]. In this technique, silver bromide (AgBr) particles in deionized water were stirred continuously to prevent sedimentation. After a few hours when the slurry was set, the polymer suture was dipped [126].

A composite of UHMWPE-PCL-Bioglass was developed as a synthetic graft by electrospinning method[133]. Bioglass was coated on UHMWPE by slurry dipping technique; melt derived glass particles were suspended in demineralized water to make a slurry with $5 \% \mathrm{w} / \mathrm{v}$ concentration, followed by 30 minutes in magnetic stirrer. Fibroblast cells were seeded on a composite graft to examine cell adhesion. Cells adhering to composite UHMWPE were well flattened and more spread out compared to cells on pure UHMWPE. Bioglass showed excellent fibroblastic cell growth on Composite UHMWPE-PCL-Bioglass synthetic graft.

Guidoin et al. [134] reported that ligaments condensed by thick collagenous tissue partly penetrated the outer layers of the braided structure in the prosthesis. This collagen penetration caused the expansion and separation of the multifilament yarns into individual fibers. However, while the knit fabric was encapsulated by thin collagenous tissue, there was no significant infiltration into the structure. Thus a hollow braided structure was designed with a core of parallel poly(vinyl alcohol) (PVA) cord wrapped by a braided diamond structure of UHMWPE threads for better mechanical performance [135]. Bach et al. [136] have been invented a hydrogel fiber for ACL reconstruction, made from PVA hydrogel. Tensile strength was enhanced by incorporating UHMWPE fibers around the PVA cord.

Zhang et al. [137] reported that UHMWPE filament was modified with Polycaprolactone for ligament and tendon regeneration. Absorbable polycaprolactone PCL has attracted mainstream attention in recent years for the development of tendon/ligament repair materials due to its excellent performance of degradation, high stability, non-toxicity, and bioresorbability [138]. Fibrous PCL has also been reported to be able to help cell growth [139].

C.C Schmidt et al. reported that growth factors play an essential role in the stimulation of fibroblast division and ligament healing. Growth factors such as platelet-derived growth factor AA, platelet-derived growth factor-BB, basic fibroblast growth factor, insulin-like growth factor 1 , and interleukin 1- alpha can enhance the proliferation of fibroblastic cells [140]. Growth factors can elicit specific biological responses such as proliferation, chemotaxis, matrix synthesis, and secretion of other growth factors, during wound healing. Molloy et al. [141] investigated some of the recent research into the functions of five growth factors whose actions were better defined during tendon healing. Five growth factors are:

* Insulin-like growth factor I (IGF-I)

4 Transforming growth factor $\beta$ (TGF - $\beta$ )

* Vascular endothelial growth factor (VEGF)

* Platelet-derived growth factor (PDGF)

* Basic fibroblast growth factor (BFGF)

Table 4: A summary of the role of the seven growth factors during tendon and ligament healing:

\begin{tabular}{|c|l|l|c|}
\hline $\begin{array}{c}\text { Growth } \\
\text { factor }\end{array}$ & $\begin{array}{l}\text { The active site of growth } \\
\text { factors }\end{array}$ & Role & Reference \\
\hline PDGF AA & $\begin{array}{l}\text { Proliferation, } \\
\text { remodeling }\end{array}$ & $\begin{array}{l}\text { Controls DNA and protein } \\
\text { synthesis at the injured site, }\end{array}$ & {$[140]$} \\
\hline
\end{tabular}




\begin{tabular}{|c|c|c|c|}
\hline & & $\begin{array}{l}\text { Controls the expression of other } \\
\text { growth factors. }\end{array}$ & \\
\hline PDGF BB & $\begin{array}{l}\text { Proliferation, } \\
\text { remodeling }\end{array}$ & $\begin{array}{l}\text { Controls DNA and protein } \\
\text { synthesis at the injured site } \\
\text { controls the expression of other } \\
\text { growth factors. }\end{array}$ & [142] \\
\hline IGF-1 & $\begin{array}{l}\text { Inflammation, } \\
\text { proliferation }\end{array}$ & $\begin{array}{l}\text { Supports the proliferation and } \\
\text { migration of cells, triggers matrix } \\
\text { production }\end{array}$ & [143] \\
\hline TGF $\beta$ & Inflammation & $\begin{array}{l}\text { Controls cell } \begin{array}{l}\text { migration, } \\
\text { expression, }\end{array} \\
\text { proteinase } \\
\text { fibronectin-binding interaction, } \\
\text { and stimulation of collagen } \\
\text { production }\end{array}$ & [141] \\
\hline VEGF & $\begin{array}{l}\text { Proliferation, } \\
\text { remodeling }\end{array}$ & Supports angiogenesis & [141] \\
\hline bFGF & $\begin{array}{l}\text { Proliferation, } \\
\text { remodeling }\end{array}$ & $\begin{array}{l}\text { Supports cellular migration, } \\
\text { angiogenesis }\end{array}$ & [140] \\
\hline IL1A & $\begin{array}{l}\text { Proliferation induces } \\
\text { pro-collagen type I and } \\
\text { III synthesis }\end{array}$ & $\begin{array}{l}\text { Supports proliferation, and } \\
\text { induction }\end{array}$ & [144] \\
\hline $\mathrm{BMP}$ & $\begin{array}{l}\text { Remodeling of impaired } \\
\text { tissues }\end{array}$ & Supports angiogenesis & [145] \\
\hline GDF & Proliferation & $\begin{array}{l}\text { Supports in ligament/tendon } \\
\text { formation }\end{array}$ & [145] \\
\hline Elastin & Proliferation & $\begin{array}{l}\text { Controls DNA and protein } \\
\text { synthesis at the injured site }\end{array}$ & [146] \\
\hline Heparin & Proliferation & $\begin{array}{l}\text { Supports the release of growth } \\
\text { factors }\end{array}$ & [147] \\
\hline $\begin{array}{l}\quad \text { PRP } \\
\text { (Platelet-rich } \\
\text { plasma) }\end{array}$ & & $\begin{array}{l}\text { Increased cellular metabolic } \\
\text { activity, reduced apoptotic rate, } \\
\text { and stimulation of collagen } \\
\text { production in the cells }\end{array}$ & [148] \\
\hline
\end{tabular}

Based on previous research studies, the biofunctionalization of UHMWPE was conducted by loading of VEGF (vascular endothelial growth factor) into UHMWPE followed by SF (Silk fibroin) coating for ACL reconstruction [149]. Firstly, UHMWPE fibers were treated with ethanol and chromic acid to remove the impurities. Chromic acid introduced additional functional groups to the surface of the fibers and etched the amorphous regions of threads. Then the chromic acid-treated UHMWPE was immersed in either SF or VEGF/SF solution at $4^{\circ} \mathrm{C}$ for 12 hours. SF loading growth factor VEGF was used to achieve the sustained release effect and to improve the neovascularization [150]. 


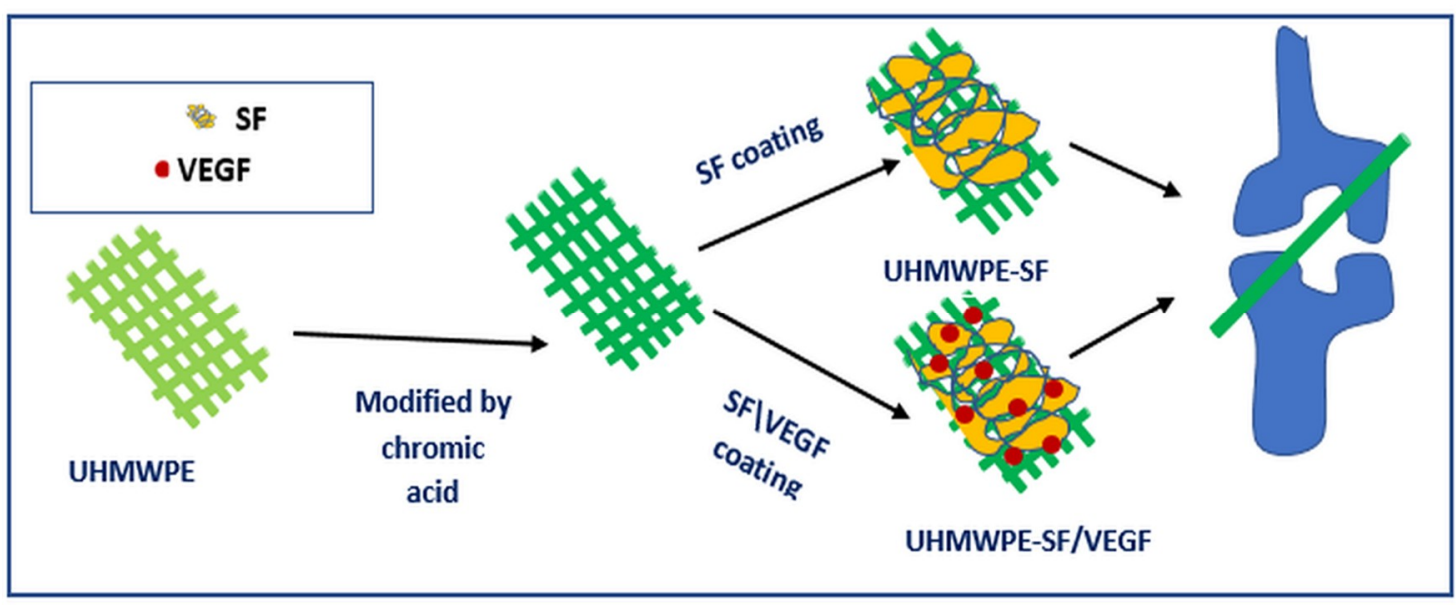

Fig 14: Schematic preparation of SF/VEGF coating [149].

\section{Conclusion:}

While many polymers, metals, ceramics, and composite materials are in use as biomaterials, ultra-high molecular weight polyethylene (UHMWPE) is one of the most important of the bioinert polymers used in the manufacture of medical implants. UHMWPE is a unique material due to its high capacity for vascularisation throughout the whole structure, which is considered a primary requirement of grafts and many other biomedical prostheses. Problems associated with the use of UHMWPE, can be resolved by modifying the surface of UHMWPE. Surface modification can improve functional properties such as mechanical properties, resistance to wear, biocompatibility, cytocompatibility, wettability, and biomaterial surface properties. Chromic acid, and hydrogen peroxide can be used to reduce the smoothness of the surface and polydopamine can be used to add functional amine groups on the surface along with protein immobilization. Bioglass and PCL coatings on UHMWPE show excellent results in fibroblastic cell adhesion assays for ligament regeneration. Recently, much attention has been focused on plasma treatment for surface modification of UHMWPE. Plasma treatment introduced a new era in surface modification compared to other methods, due to its simple, straightforward mechanism and it can improve the hydrophilicity of materials. It is relatively safe, doesn't need any solvent for treatment, requires short processing times, and it can be applied to various materials. Plasma treatment can even sterilize surfaces if needed. Among different plasma methods, Plasma immersion ion implantation (PIII) is receiving attention due to the biofunctionalization of materials with protein immobilization techniques. The surface functionalization of UHMWPE is quite straightforward, and surface treatments can be used to change only the surface properties without affecting the bulk properties of the material. Ligament/tendon reconstruction is considered a promising research application area for UHMWPE. Owing to the extreme hydrophobicity of UHMWPE and its surface chemistry, which is very different from that of natural ligaments and tendons, modern ACL reconstructions do not enjoy the low friction and wear of the original ligaments. Surface functionalization of biomaterials for ligaments/tendons is currently being further developed, with the potential for improved outcomes for patients. The surface improvement of UHMWPE with the PIII technique can make the surface bioactive for cell adhesion and display the signalization motifs in biological molecules. With the PIII technique, the immobilization of biomolecules is convenient and efficient for the biofunctionalization of biomaterials.

\section{References}

(1) Kurtz, S. M. 4 The Origins of UHMWPE in Total Hip Arthroplasty, Third Edit.; Elsevier Inc., 1982. https://doi.org/10.1016/B978-0-323-35401-1/00004-1. 
(2) Kurtz, S. M. 4 The Origins of UHMWPE in Total Hip Arthroplasty, Third Edit.; Elsevier Inc., 1982. https://doi.org/10.1016/B978-0-323-35401-1/00004-1.

(3) Oosterom, R.; Ahmed, T. J.; Poulis, J. A.; Bersee, H. E. N. Adhesion Performance of UHMWPE after Different Surface Modification Techniques. Med. Eng. Phys. 2006, 28 (4), 323-330. https://doi.org/10.1016/j.medengphy.2005.07.009.

(4) Gilman, A. B.; Piskarev, M. S.; Kuznetsov, A. A.; Ozerin, A. N. Modification of Ultrahigh-MolecularWeight Polyethylene by Low-Temperature Plasma (Review). High Energy Chem. 2017, 51 (2), 136-144. https://doi.org/10.1134/S0018143917020059.

(5) Liu, Q.; Li, W.; Cao, L.; Wang, J.; Qu, Y.; Wang, X.; Qiu, R.; Di, X.; Wang, Z.; Liang, B. Response of MG63 Osteoblast Cells to Surface Modification of Ti-6Al-4V Implant Alloy by Laser Interference Lithography. J. Bionic Eng. 2017, 14 (3), 448-458. https://doi.org/10.1016/S1672-6529(16)60410-9.

(6) Zhu, X.; Chen, J.; Scheideler, L.; Reichl, R.; Geis-Gerstorfer, J. Effects of Topography and Composition of Titanium Surface Oxides on Osteoblast Responses. Biomaterials 2004, 25 (18), 4087-4103. https://doi.org/10.1016/j.biomaterials.2003.11.011.

(7) Ge, S.; Wang, Q.; Zhang, D.; Zhu, H.; Xiong, D.; Huang, C.; Huang, X. Friction and Wear Behavior of Nitrogen Ion Implanted UHMWPE against ZrO2 Ceramic. Wear 2003, 255 (7-12), 1069-1075. https://doi.org/10.1016/S0043-1648(03)00269-2.

(8) Avinash Patil, N.; Njuguna, J.; Kandasubramanian, B. UHMWPE for Biomedical Applications: Performance and Functionalization. Eur. Polym. J. 2020, 125 (January), 109529. https://doi.org/10.1016/j.eurpolymj.2020.109529.

(9) Stewart, C.; Akhavan, B.; Wise, S. G.; Bilek, M. M. M. A Review of Biomimetic Surface Functionalization for Bone-Integrating Orthopedic Implants: Mechanisms, Current Approaches, and Future Directions. Prog. Mater. Sci. 2019, 106 (July), 100588. https://doi.org/10.1016/j.pmatsci.2019.100588.

(10) Bracco, P.; Brunella, V.; Luda, M. P.; Zanetti, M.; Costa, L. Radiation-Induced Crosslinking of UHMWPE in the Presence of Co-Agents: Chemical and Mechanical Characterisation. Polymer (Guildf). 2005, 46 (24), 10648 10657. https://doi.org/10.1016/j.polymer.2005.08.095.

(11) Shen, J.; Costa, L.; Xu, Y.; Cong, Y.; Cheng, Y.; Liu, X.; Fu, J. Stabilization of Highly Crosslinked Ultra High Molecular Weight Polyethylene with Natural Polyphenols. Polym. Degrad. Stab. 2014, 105 (1), 197-205. https://doi.org/10.1016/j.polymdegradstab.2014.04.018.

(12) Serro, A. P.; Degiampietro, K.; Colaço, R.; Saramago, B. Adsorption of Albumin and Sodium Hyaluronate on UHMWPE: A QCM-D and AFM Study. Colloids Surfaces B Biointerfaces 2010, 78 (1), 1-7. https://doi.org/10.1016/j.colsurfb.2010.01.022.

(13) Yang, Z.; Peng, H.; Wang, W.; Liu, T. Crystallization Behavior of Poly(E-Caprolactone)/Layered Double Hydroxide Nanocomposites. J. Appl. Polym. Sci. 2010, 116 (5), 2658-2667. https://doi.org/10.1002/app.

(14) Kostov, K. G.; Ueda, M.; Tan, I. H.; Leite, N. F.; Beloto, A. F.; Gomes, G. F. Structural Effect of Nitrogen Plasma-Based Ion Implantation on Ultra-High Molecular Weight Polyethylene. Surf. Coatings Technol. 2004, 186 (1-2 SPEC. ISS.), 287-290. https://doi.org/10.1016/j.surfcoat.2004.03.033. 
(15) Jiang, J. H.; Zhu, L. P.; Li, X. L.; Xu, Y. Y.; Zhu, B. K. Surface Modification of PE Porous Membranes Based on the Strong Adhesion of Polydopamine and Covalent Immobilization of Heparin. J. Memb. Sci. 2010, 364 (12), 194-202. https://doi.org/10.1016/j.memsci.2010.08.017.

(16) Silverstein, M. S.; Breuer, O.; Dodiuk, H. Surface Modification of UHMWPE Fibers. J. Appl. Polym. Sci. 1994, 52 (12), 1785-1795. https://doi.org/10.1002/app.1994.070521213.

(17) Kang, K.; Choi, I. S.; Nam, Y. A Biofunctionalization Scheme for Neural Interfaces Using Polydopamine Polymer. Biomaterials 2011, 32 (27), 6374-6380. https://doi.org/10.1016/j.biomaterials.2011.05.028.

(18) Sa, R.; Wei, Z.; Yan, Y.; Wang, L.; Wang, W.; Zhang, L.; Ning, N.; Tian, M. Catechol and Epoxy Functionalized Ultrahigh Molecular Weight Polyethylene (UHMWPE) Fibers with Improved Surface Activity and Interfacial Adhesion. Compos. Sci. Technol. 2015, 113, 54-62.

https://doi.org/10.1016/j.compscitech.2015.03.017.

(19) Liu, R.; Wang, X.; Yu, J.; Wang, Y.; Zhu, J.; Hu, Z. Surface Modification of UHMWPE/Fabric Composite Membrane via Self-Polymerized Polydopamine Followed by MPEG-NH2 Immobilization. J. Appl. Polym. Sci. 2018, 135 (26), 1-11. https://doi.org/10.1002/app.46428.

(20) Hu, J.; Feng, X.; Liu, Z.; Zhao, Y.; Chen, L. Surface Amine-Functionalization of UHMWPE Fiber by BioInspired Polydopamine and Grafted Hexamethylene Diamine. Surf. Interface Anal. 2017, 49 (7), 640-646. https://doi.org/10.1002/sia.6203.

(21) Chen, S.; Fu, P.; Wu, H.; Pei, M. Meniscus, Articular Cartilage and Nucleus Pulposus: A Comparative Review of Cartilage-like Tissues in Anatomy, Development and Function. Cell Tissue Res. 2017, 370 (1), 53-70. https://doi.org/10.1007/s00441-017-2613-0.

(22) Hlaváček, M. The Influence of the Acetabular Labrum Seal, Intact Articular Superficial Zone and Synovial Fluid Thixotropy on Squeeze-Film Lubrication of a Spherical Synovial Joint. J. Biomech. 2002, 35 (10), 13251335. https://doi.org/10.1016/S0021-9290(02)00172-0.

(23) Nichols, S. P.; Koh, A.; Storm, W. L.; Shin, J. H.; Schoenfisch, M. H. Biocompatible Materials for Continuous Glucose Monitoring Devices. Chem. Rev. 2013, 113 (4), 2528-2549. https://doi.org/10.1021/cr300387j.

(24) Gu, X.; Zheng, Y.; Cheng, Y.; Zhong, S.; Xi, T. In Vitro Corrosion and Biocompatibility of Binary Magnesium Alloys. Biomaterials 2009, 30 (4), 484-498. https://doi.org/10.1016/j.biomaterials.2008.10.021.

(25) Lee, S. S.; Hughes, P. M.; Robinson, M. R. Recent Advances in Drug Delivery Systems for Treating Ocular Complications of Systemic Diseases. Curr. Opin. Ophthalmol. 2009, 20 (6), 511-519.

https://doi.org/10.1097/ICU.0b013e328330ccb9.

(26) Schoonen, L.; Van Hest, J. C. M. Functionalization of Protein-Based Nanocages for Drug Delivery Applications. Nanoscale 2014, 6 (13), 7124-7141. https://doi.org/10.1039/c4nr00915k.

(27) Koseki, H.; Yonekura, A.; Shida, T.; Yoda, I.; Horiuchi, H.; Morinaga, Y.; Yanagihara, K.; Sakoda, H.; Osaki, M.; Tomita, M. Early Staphylococcal Biofilm Formation on Solid Orthopaedic Implant Materials: In Vitro Study. PLoS One 2014, 9 (10), 1-8. https://doi.org/10.1371/journal.pone.0107588.

(28) Weng, C. N.; Molof, A. H. Nitrification in the Biological Fixed Film Rotating Disk System. J. Water Pollut. Control Fed. 1974, 46 (7), 1674-1685. 
(29) Tang, L.; Wang, Y.; Li, J. The Graphene/Nucleic Acid Nanobiointerface. Chem. Soc. Rev. 2015, 44 (19), 6954-6980. https://doi.org/10.1039/c4cs00519h.

(30) Tie, D.; Feyerabend, F.; Müller, W.-D.; Schade, R.; Liefeith, K.; Kainer, K.; Willumeit, R. Antibacterial Biodegradable Mg-Ag Alloys. Eur. Cells Mater. 2013, 25, 284-298. https://doi.org/10.22203/ecm.v025a20.

(31) Dolanský, J.; Henke, P.; Kubát, P.; Fraix, A.; Sortino, S.; Mosinger, J. Polystyrene Nanofiber Materials for Visible-Light-Driven Dual Antibacterial Action via Simultaneous Photogeneration of NO and O2(18g). ACS Appl. Mater. Interfaces 2015, 7 (41), 22980-22989. https://doi.org/10.1021/acsami.5b06233.

(32) Yoshida, S.; Hagiwara, K.; Hasebe, T.; Hotta, A. Surface Modification of Polymers by Plasma Treatments for the Enhancement of Biocompatibility and Controlled Drug Release. Surf. Coatings Technol. 2013, 233, 99-107. https://doi.org/10.1016/j.surfcoat.2013.02.042.

(33) Ratner, B. D. The Engineering of Biomaterials Exhibiting Recognition and Specificity. J. Mol. Recognit. 1996, 9 (5-6), 617-625. https://doi.org/10.1002/(SICI)1099-1352(199634/12)9:5/6<617::AID-JMR310>3.0.CO;2-D.

(34) Hegemann, D.; Brunner, H.; Oehr, C. Plasma Treatment of Polymers for Surface and Adhesion Improvement. Nucl. Instruments Methods Phys. Res. Sect. B Beam Interact. with Mater. Atoms 2003, 208 (1-4), 281286. https://doi.org/10.1016/S0168-583X(03)00644-X.

(35) Brès, L.; Sanchot, A.; Rives, B.; Gherardi, N.; Naudé, N.; Aufray, M. Fine-Tuning of Chemical and Physical Polymer Surface Modifications by Atmospheric Pressure Post-Discharge Plasma and Its Correlation with Adhesion Improvement. Surf. Coatings Technol. 2019, 362 (July 2018), 388-396.

https://doi.org/10.1016/j.surfcoat.2019.01.102.

(36) Lai, J.; Sunderland, B.; Xue, J.; Yan, S.; Zhao, W.; Folkard, M.; Michael, B. D.; Wang, Y. Study on Hydrophilicity of Polymer Surfaces Improved by Plasma Treatment. Appl. Surf. Sci. 2006, 252 (10), 3375-3379. https://doi.org/10.1016/j.apsusc.2005.05.038.

(37) Riveiro, A.; Soto, R.; Del Val, J.; Comesaña, R.; Boutinguiza, M.; Quintero, F.; Lusquiños, F.; Pou, J. Laser Surface Modification of Ultra-High-Molecular-Weight Polyethylene (UHMWPE) for Biomedical Applications. Appl. Surf. Sci. 2014, 302, 236-242. https://doi.org/10.1016/j.apsusc.2014.02.130.

(38) Yu, H.; Perni, S.; Shi, J. J.; Wang, D. Z.; Kong, M. G.; Shama, G. Effects of Cell Surface Loading and Phase of Growth in Cold Atmospheric Gas Plasma Inactivation of Escherichia Coli K12. J. Appl. Microbiol. 2006, 101 (6), 1323-1330. https://doi.org/10.1111/j.1365-2672.2006.03033.x.

(39) Perni, S.; Kong, M. G.; Prokopovich, P. Cold Atmospheric Pressure Gas Plasma Enhances the Wear Performance of Ultra-High Molecular Weight Polyethylene. Acta Biomater. 2012, 8 (3), 1357-1365. https://doi.org/10.1016/j.actbio.2011.12.007.

(40) Ouf, S. A.; Mohamed, A. A. H.; El-Sayed, W. S. Fungal Decontamination of Fleshy Fruit Water Washes by Double Atmospheric Pressure Cold Plasma. Clean - Soil, Air, Water 2016, 44 (2), 134-142. https://doi.org/10.1002/clen.201400575.

(41) Rodrigues, M. M.; Fontoura, C. P.; Garcia, C. S. C.; Martins, S. T.; Henriques, J. A. P.; Figueroa, C. A.; Roesch-Ely, M.; Aguzzoli, C. Investigation of Plasma Treatment on UHMWPE Surfaces: Impact on Physicochemical Properties, Sterilization and Fibroblastic Adhesion. Mater. Sci. Eng. C 2019, 102 (March), 264275. https://doi.org/10.1016/j.msec.2019.04.048. 
(42) Factors-Affecting-the-Interfacial-Adhesion-of-Ultrahighmodulus-Polyethylene-FibrevinylesterComposites-Using-Gas-Plasma-Treatment1998Journal-of-Materials-Science.Pdf.

(43) Liang, H.; Shi, B.; Fairchild, A.; Cale, T. Applications of Plasma Coatings in Artificial Joints: An Overview. Vacuum 2004, 73 (3-4), 317-326. https://doi.org/10.1016/j.vacuum.2003.12.160.

(44) Struszczyk, mh; Puszkarz, ak; Wilbik-Hałgas, B.; Cichecka, M.; Litwa, P.; Urbaniak-Domagała, W.; Krucinska, I. The Surface Modification of Ballistic Textiles Using Plasma-Assisted Chemical Vapor Deposition (PACVD). Text. Res. J. 2014, 84 (19), 2085-2093. https://doi.org/10.1177/0040517514528559.

(45) More, S. E.; Dave, J. R.; Makar, P. K.; Bhoraskar, S. V.; Premkumar, S.; Tomar, G. B.; Mathe, V. L. Surface Modification of UHMWPE Using ECR Plasma for Osteoblast and Osteoclast Differentiation. Appl. Surf. Sci. 2019, No. October, 144665. https://doi.org/10.1016/j.apsusc.2019.144665.

(46) Mwale, F.; Wang, H. T.; Nelea, V.; Luo, L.; Antoniou, J.; Wertheimer, M. R. The Effect of Glow Discharge Plasma Surface Modification of Polymers on the Osteogenic Differentiation of Committed Human Mesenchymal Stem Cells. Biomaterials 2006, 27 (10), 2258-2264.

https://doi.org/10.1016/j.biomaterials.2005.11.006.

(47) Liu, H.; Xie, D.; Qian, L.; Deng, X.; Leng, Y. X.; Huang, N. The Mechanical Properties of the Ultrahigh Molecular Weight Polyethylene (UHMWPE) Modified by Oxygen Plasma. Surf. Coatings Technol. 2011, 205 (89), 2697-2701. https://doi.org/10.1016/j.surfcoat.2010.08.120.

(48) Ren, Y.; Ding, Z.; Wang, C.; Zang, C.; Zhang, Y.; Xu, L. Influence of DBD Plasma Pretreatment on the Deposition of Chitosan onto UHMWPE Fiber Surfaces for Improvement of Adhesion and Dyeing Properties. Appl. Surf. Sci. 2017, 396, 1571-1579. https://doi.org/10.1016/j.apsusc.2016.11.215.

(49) Activity, A. Characterization of Biopolymer and Chitosan -Based Nanocomposites with Antimicrobial Activity. 2013.

(50) John R. Conrad. Method and Apparatus for Plasma Source Ion Implantation. 1987, 252 (3), 102-113.

(51) Conrad, J. R.; Radtke, J. L.; Dodd, R. A.; Worzala, F. J.; Tran, N. C. Plasma Source Ion-Implantation Technique for Surface Modification of Materials. J. Appl. Phys. 1987, 62 (11), 4591-4596. https://doi.org/10.1063/1.339055.

(52) Biederman, H. Polymer Films Prepared by Plasma Polymerization and Their Potential Application. Vacuum 1987, 37 (3-4), 367-373. https://doi.org/10.1016/0042-207X(87)90027-3.

(53) Gutensohn, K.; Beythien, C.; Bau, J.; Fenner, T.; Grewe, P.; Koester, R.; Padmanaban, K.; Kuehnl, P. In Vitro Analyses of Diamond-like Carbon Coated Stents: Reduction of Metal Ion Release, Platelet Activation, and Thrombogenicity. Thromb. Res. 2000, 99 (6), 577-585. https://doi.org/10.1016/S0049-3848(00)00295-4.

(54) Bilek, M. M.; McKenzie, D. R. Plasma Modified Surfaces for Covalent Immobilization of Functional Biomolecules in the Absence of Chemical Linkers: Towards Better Biosensors and a New Generation of Medical Implants. Biophys. Rev. 2010, 2 (2), 55-65. https://doi.org/10.1007/s12551-010-0028-1.

(55) Pelletier, J.; Anders, A. Plasma-Based Ion Implantation and Deposition: A Review of Physics, Technology, and Applications. IEEE Trans. Plasma Sci. 2005, 33 (6 I), 1944-1959. https://doi.org/10.1109/TPS.2005.860079.

(56) Lu, T.; Qiao, Y.; Liu, X. Surface Modification of Biomaterials Using Plasma Immersion Ion Implantation 
and Deposition. Interface Focus 2012, 2 (3), 325-336. https://doi.org/10.1098/rsfs.2012.0003.

(57) Nedela, O.; Slepicka, P.; Švorcík, V. Surface Modification of Polymer Substrates for Biomedical Applications. Materials (Basel). 2017, 10 (10). https://doi.org/10.3390/ma10101115.

(58) Gleiter, H. Improving the Biocompatibility of Medical Implants with Plasma Immersion Ion Implantation. Prog. Mater. Sci. 1989, 33 (4), 233. https://doi.org/10.1016/S0257-8972(02)00085-3.

(59) Bakkar, A.; Neubert, V. Improving Corrosion Resistance of Magnesium-Based Alloys by Surface Modification with Hydrogen by Electrochemical Ion Reduction (EIR) and by Plasma Immersion Ion Implantation (PIII). Corros. Sci. 2005, 47 (5), 1211-1225. https://doi.org/10.1016/j.corsci.2004.06.027.

(60) Wong, L. S.; Khan, F.; Micklefield, J. Selective Covalent Protein Immobilization: Strategies and Applications. Chem. Rev. 2009, 109 (9), 4025-4053. https://doi.org/10.1021/cr8004668.

(61) Lee, Y.; Han, S.; Lim, H.; Kim, Y.; Kim, H. Surface Analysis of Polymers Electrically Improved by PlasmaSource Ion-Implantation. Anal. Bioanal. Chem. 2002, 373 (7), 595-600. https://doi.org/10.1007/s00216-002-1374-z.

(62) Denes, F.; Young, R. A.; Sarmadi, M. Surface Functionalization of Polymers under Cold Plasma Conditions-A Mechanistic Approach. J. Photopolym. Sci. Technol. 2008, 10 (1), 91-112. https://doi.org/10.2494/photopolymer.10.91.

(63) Shi, W.; Li, X. Y.; Dong, H. Improved Wear Resistance of Ultra-High Molecular Weight Polyethylene by Plasma Immersion Ion Implantation. Wear 2001, 250-251 (PART 1), 544-552. https://doi.org/10.1016/S00431648(01)00636-6.

(64) Huang, N.; Yang, P.; Leng, Y. X.; Wang, J.; Sun, H.; Chen, J. Y.; Wan, G. J. Surface Modification of Biomaterials by Plasma Immersion Ion Implantation. Surf. Coatings Technol. 2004, 186 (1-2 SPEC. ISS.), $218-226$. https://doi.org/10.1016/j.surfcoat.2004.04.041.

(65) Chen, J.; Zhu, F.; Pan, H.; Cao, J.; Zhu, D.; Xu, H.; Cai, Q.; Shen, J.; Chen, L.; He, Z. Surface Modification of Ion Implanted Ultra High Molecular Weight Polyethylene. Nucl. Instruments Methods Phys. Res. Sect. B Beam Interact. with Mater. Atoms 2000, 169 (1-4), 26-30. https://doi.org/10.1016/S0168-583X(00)00011-2.

(66) Czvikovszky, T. Reactive Recycling of Multiphase Polymer Systems through Electron Beam. Nucl. Inst. Methods Phys. Res. B 1995, 105 (1-4), 233-237. https://doi.org/10.1016/0168-583X(95)00528-5.

(67) Lee, E. H.; Rao, G. R.; Lewis, M. B.; Mansur, L. K. Ion Beam Application for Improved Polymer Surface Properties. Nucl. Inst. Methods Phys. Res. B 1993, 74 (1-2), 326-330. https://doi.org/10.1016/0168-583X(93)95070L.

(68) Klaumünzer, S.; Zhu, Q. Q.; Schnabel, W.; Schumacher, G. Ion-Beam-Induced Crosslinking of Polystyrene - Still an Unsolved Puzzle. Nucl. Instruments Methods Phys. Res. Sect. B Beam Interact. with Mater. Atoms 1996, 116 (1-4), 154-158. https://doi.org/10.1016/0168-583X(96)00028-6.

(69) Farm, D. F.; Brain, A. A. The Microstructure of Ultra-High Molecular Weight Polyethylene Used in Total Joint Replacements. 1998, 18 (24), 1677-1685.

(70) Wu, G.; Feng, K.; Shanaghi, A.; Zhao, Y.; Xu, R.; Yuan, G.; Chu, P. K. Effects of Surface Alloying on Electrochemical Corrosion Behavior of Oxygen-Plasma-Modified Biomedical Magnesium Alloy. Surf. Coatings Technol. 2012, 206 (14), 3186-3195. https://doi.org/10.1016/j.surfcoat.2012.01.001. 
(71) An, Y. H.; Alvi, F. I.; Kang, Q.; Laberge, M.; Drews, M. J.; Zhang, J.; Matthews, M. A.; Arciola, C. R. Effects of Sterilization on Implant Mechanical Property and Biocompatibility. Int. J. Artif. Organs 2005, 28 (11), 11261137. https://doi.org/10.1177/039139880502801110.

(72) Hu, J.; Gao, Q.; Xu, L.; Zhang, M.; Xing, Z.; Guo, X.; Zhang, K.; Wu, G. Significant Improvement in Thermal and UV Resistances of UHMWPE Fabric through in Situ Formation of Polysiloxane-TiO2 Hybrid Layers. ACS Appl. Mater. Interfaces 2016, 8 (35), 23311-23320. https://doi.org/10.1021/acsami.6b04914.

(73) Costa, L.; Luda, M. P.; Trossarelli, L.; Brach Del Prever, E. M.; Crova, M.; Gallinaro, P. Oxidation in Orthopaedic UHMWPE Sterilized by Gamma-Radiation and Ethylene Oxide. Biomaterials 1998, 19 (7-9), 659668. https://doi.org/10.1016/S0142-9612(97)00160-9.

(74) Ianuzzi, A.; Mkandawire, C. Applications of UHMWPE in Total Ankle Replacements, Third Edit.; Elsevier Inc., 2009. https://doi.org/10.1016/B978-0-12-374721-1.00011-0.

(75) Wang, J.; Liang, G.; Zhao, W.; Lü, S.; Zhang, Z. Studies on Surface Modification of UHMWPE Fibers via UV Initiated Grafting. Appl. Surf. Sci. 2006, 253 (2), 668-673. https://doi.org/10.1016/j.apsusc.2005.12.165.

(76) Ma, Y.; Liu, L.; Yang, W. Photo-Induced Living/Controlled Surface Radical Grafting Polymerization and Its Application in Fabricating 3-D Micro-Architectures on the Surface of Flat/Particulate Organic Substrates. Polymer (Guildf). 2011, 52 (19), 4159-4173. https://doi.org/10.1016/j.polymer.2011.07.027.

(77) Cho, E. H.; Lee, S. G.; Kim, J. K. Surface Modification of UHMWPE with $\gamma$-Ray Radiation for Improving Interfacial Bonding Strength with Bone Cement (II). Curr. Appl. Phys. 2005, 5 (5), 475-479. https://doi.org/10.1016/j.cap.2005.01.013.

(78) Tomita, N.; Kitakura, T.; Onmori, N.; Ikada, Y.; Aoyama, E. Prevention of Fatigue Cracks in Ultrahigh Molecular Weight Polyethylene Joint Components by the Addition of Vitamin E. J. Biomed. Mater. Res. 1999, 48 (4), 474-478. https://doi.org/10.1002/(SICI)1097-4636(1999)48:4<474::AID-JBM11>3.0.CO;2-T.

(79) Puppulin, L.; Leto, A.; Hasegawa, M.; Pezzotti, G. A Comparative Microstructural Study of Vitamin-E Blended and Infused Highly Crosslinked UHMWPE for Total Knee Arthroplasty. J. Mech. Behav. Biomed. Mater. 2014, 39, 247-256. https://doi.org/10.1016/j.jmbbm.2014.07.029.

(80) Banche, G.; Bracco, P.; Bistolfi, A.; Allizond, V.; Boffano, M.; Costa, L.; Cimino, A.; Cuffini, A. M.; Del Prever, E. M. B. Vitamin e Blended Uhmwpe May Have the Potential to Reduce Bacterial Adhesive Ability. J. Orthop. Res. 2011, 29 (11), 1662-1667. https://doi.org/10.1002/jor.21432.

(81) Banche, G.; Bracco, P.; Allizond, V.; Bistolfi, A.; Boffano, M.; Cimino, A.; Brach del Prever, E. M.; Cuffini, A. M. Do Crosslinking and Vitamin E Stabilization Influence Microbial Adhesions on UHMWPE-Based Biomaterials? Clin. Orthop. Relat. Res. 2015, 473 (3), 974-986. https://doi.org/10.1007/s11999-014-4024-9.

(82) Meng, C.; Chen, Y.; Xie, M.; Yu, Z.; Yang, B. Surface Modification of Ultrahigh Molecular Weight Polyethylene by Plasma-Induced in-Situ Grafting with Vinyl Triethoxysilane. J. Biomed. Mater. Res. - Part A 2018, 106 (2), 321-332. https://doi.org/10.1002/jbm.a.36241.

(83) Cools, P.; Van Vrekhem, S.; De Geyter, N.; Morent, R. The Use of DBD Plasma Treatment and Polymerization for the Enhancement of Biomedical UHMWPE. Thin Solid Films 2014, 572, 251-259. https://doi.org/10.1016/j.tsf.2014.08.033. 
(84) Aziz, G.; De Geyter, N.; Declercq, H.; Cornelissen, R.; Morent, R. Incorporation of Amine Moieties onto Ultra-High Molecular Weight Polyethylene (UHMWPE) Surface via Plasma and UV Polymerization of Allylamine. Surf. Coatings Technol. 2015, 271, 39-47. https://doi.org/10.1016/j.surfcoat.2015.01.027.

(85) Rusmini, F.; Zhong, Z.; Feijen, J. Protein Immobilization Strategies for Protein Biochips. Biomacromolecules 2007, 8 (6), 1775-1789. https://doi.org/10.1021/bm061197b.

(86) Puertas, S.; de Gracia Villa, M.; Mendoza, E.; Jiménez-Jorquera, C.; de la Fuente, J. M.; FernándezSánchez, C.; Grazú, V. Improving Immunosensor Performance through Oriented Immobilization of Antibodies on Carbon Nanotube Composite Surfaces. Biosens. Bioelectron. 2013, 43, 274-280.

https://doi.org/10.1016/j.bios.2012.12.010.

(87) Yang, Z.; Wang, J.; Luo, R.; Maitz, M. F.; Jing, F.; Sun, H.; Huang, N. The Covalent Immobilization of Heparin to Pulsed-Plasma Polymeric Allylamine Films on 316L Stainless Steel and the Resulting Effects on Hemocompatibility. Biomaterials 2010, 31 (8), 2072-2083. https://doi.org/10.1016/j.biomaterials.2009.11.091.

(88) Weetall, H. H. Preparation of Immobilized Proteins Covalently Coupled through Silane Coupling Agents to Inorganic Supports. Appl. Biochem. Biotechnol. 1993, 41 (3), 157-188. https://doi.org/10.1007/BF02916421.

(89) Coad, B. R.; Jasieniak, M.; Griesser, S. S.; Griesser, H. J. Controlled Covalent Surface Immobilisation of Proteins and Peptides Using Plasma Methods. Surf. Coatings Technol. 2013, 233, 169-177. https://doi.org/10.1016/j.surfcoat.2013.05.019.

(90) Cruz, G. J.; Gómez, L. M.; Gonzalez-Torres, M.; Gonzalez-Salgado, F.; Basurto, R.; Colín, E.; Palacios, J. C.; Olayo, M. G. Polymerization Mechanisms in Plasma Polyallylamine. J. Mater. Sci. 2017, 52 (2), 1005-1013. https://doi.org/10.1007/s10853-016-0396-4.

(91) Kondyurin, A.; Nosworthy, N. J.; Bilek, M. M. M. Effect of Low Molecular Weight Additives on Immobilization Strength, Activity, and Conformation of Protein Immobilized on PVC AndUHMWPE. Langmuir 2011, 27 (10), 6138-6148. https://doi.org/10.1021/la200376f.

(92) Shukla, S. P.; Devi, S. Covalent Coupling of Peroxidase to a Copolymer of Acrylamide (AAm)-2Hydroxyethyl Methaacrylate (HEMA) and Its Use in Phenol Oxidation. Process Biochem. 2005, 40 (1), 147-154. https://doi.org/10.1016/j.procbio.2003.11.051.

(93) Fernandes, K. F.; Lima, C. S.; Pinho, H.; Collins, C. H. Immobilization of Horseradish Peroxidase onto Polyaniline Polymers. Process Biochem. 2003, 38 (9), 1379-1384. https://doi.org/10.1016/S0032-9592(03)00021-9.

(94) Whittle, J. D.; Bullett, N. A.; Short, R. D.; Ian Douglas, C. W.; Hollander, A. P.; Davies, J. Adsorption of Vitronectin, Collagen and Immunoglobulin-G to Plasma Polymer Surfaces by Enzyme Linked Immunosorbent Assay (ELISA). J. Mater. Chem. 2002, 12 (9), 2726-2732. https://doi.org/10.1039/b201471h.

(95) Bohnert, J. L.; Fowler, B. C.; Horbett, T. A.; Hoffman, A. S. Plasma Gas Discharge Deposited Fluorocarbon Polymers Exhibit Reduced Elutability of Adsorbed Albumin and Fibrinogen. J. Biomater. Sci. Polym. Ed. 1989, 1 (4), 279-297. https://doi.org/10.1163/156856289X00154.

(96) Dekker, A.; Reitsma, K.; Beugeling, T.; Bantjes, A.; Feijen, J.; van Aken, W. G. Adhesion of Endothelial Cells and Adsorption of Serum Proteins on Gas Plasma-Treated Polytetrafluoroethylene. Biomaterials 1991, 12 (2), 130-138. https://doi.org/10.1016/0142-9612(91)90191-C. 
(97) Chandy, T.; Das, G. S.; Wilson, R. F.; Rao, G. H. R. Use of Plasma Glow for Surface-Engineering Biomolecules to Enhance Bloodcompatibility of Dacron and PTFE Vascular Prosthesis. Biomaterials 2000, 21 (7), 699-712. https://doi.org/10.1016/S0142-9612(99)00231-8.

(98) Poncin-Epaillard, F.; Legeay, G. Surface Engineering of Biomaterials with Plasma Techniques. J. Biomater. Sci. Polym. Ed. 2003, 14 (10), 1005-1028. https://doi.org/10.1163/156856203769231538.

(99) Browne, M. M.; Lubarsky, G. V.; Davidson, M. R.; Bradley, R. H. Protein Adsorption onto Polystyrene Surfaces Studied by XPS and AFM. Surf. Sci. 2004, 553 (1-3), 155-167. https://doi.org/10.1016/j.susc.2004.01.046.

(100) Vasilets, V. N.; Kuznetsov, A. V.; Sevastianov, V. I. Vacuum Ultraviolet Treatment of Polyethylene to Change Surface Properties and Characteristics of Protein Adsorption. J. Biomed. Mater. Res. - Part A 2004, 69 (3), 428-435. https://doi.org/10.1002/jbm.a.30005.

(101) Yanagisawa, K.; Murakami, T. N.; Tokuoka, Y.; Ochiai, A.; Takahashi, M.; Kawashima, N. Immobilization and Enzymatic Activity of Glucose Oxidase on Polystyrene Surface Modified with Ozone Aeration and UV Irradiation in Distilled Water and/or Aqueous Ammonia Solution. Colloids Surfaces B Biointerfaces 2006, 48 (1), 67-71. https://doi.org/10.1016/j.colsurfb.2006.01.008.

(102) Lubarsky, G. V.; Browne, M. M.; Mitchell, S. A.; Davidson, M. R.; Bradley, R. H. The Influence of Electrostatic Forces on Protein Adsorption. Colloids Surfaces B Biointerfaces 2005, 44 (1), 56-63. https://doi.org/10.1016/j.colsurfb.2005.05.010.

(103) Teodoru, S.; Kusano, Y.; Rozlosnik, N.; Michelsen, P. K. Continuous Plasma Treatment of UltraHigh-Molecular-Weight Polyethylene (UHMWPE) Fibres for Adhesion Improvement. Plasma Process. Polym. 2009, 6 (SUPPL. 1), 375-381. https://doi.org/10.1002/ppap.200930906.

(104) Widmer, M. R.; Heuberger, M.; Vörös, J.; Spencer, N. D. Influence of Polymer Surface Chemistry on Frictional Properties under Protein-Lubrication Conditions: Implications for Hip-Implant Design. Tribol. Lett. 2001, 10 (1-2), 111-116. https://doi.org/10.1023/A:1009074228662.

(105) Bočková, J.; Vojtová, L.; Přrikryl, R.; Čechal, J.; Jančář, J. Collagen-Grafted Ultra-High Molecular Weight Polyethylene for Biomedical Applications. Chem. Pap. 2008, 62 (6), 580-588. https://doi.org/10.2478/s11696-008-0076-1.

(106) Ho, J. P. Y.; Nosworthy, N. J.; Bilek, M. M. M.; Gan, B. K.; McKenzie, D. R.; Chu, P. K.; dos Remedios, C. G. Plasma-Treated Polyethylene Surfaces for Improved Binding of Active Protein. Plasma Process. Polym. 2007, 4 (5), 583-590. https://doi.org/10.1002/ppap.200600182.

(107) Gan, B. K.; Nosworthy, N. J.; McKenzie, D. R.; Dos Remedios, C. G.; Bilek, M. M. M. Plasma Immersion Ion Implantation Treatment of Polyethylene for Enhanced Binding of Active Horseradish Peroxidase. J. Biomed. Mater. Res. - Part A 2008, 85 (3), 605-610. https://doi.org/10.1002/jbm.a.31612.

(108) Bilek, M. M. M. Biofunctionalization of Surfaces by Energetic Ion Implantation: Review of Progress on Applications in Implantable Biomedical Devices and Antibody Microarrays. Appl. Surf. Sci. 2014, 310, 3-10. https://doi.org/10.1016/j.apsusc.2014.03.097.

(109) Chehab, E. L.; Flik, K. R.; Vidal, A. F.; Levinson, M.; Gallo, R. a; Altchek, D. W.; Warren, R. F. Anterior Cruciate Ligament Reconstruction Using Achilles Tendon Allograft: An Assessment of Outcome for Patients Age 30 Years and Older. HSS J. 2011, 7, 44-51. https://doi.org/10.1007/s11420-010-9183-y. 
(110) Ge, Z.; Yang, F.; Goh, J. C. H.; Ramakrishna, S.; Lee, E. H. Review Biomaterials and Scaffolds for Ligament Tissue Engineering. 2006. https://doi.org/10.1002/jbm.a.

(111) Van Oeveren, W.; Tielliu, I. F.; De Hart, J. Comparison of Modified Chandler, Roller Pump, and Ball Valve Circulation Models for in Vitro Testing in High Blood Flow Conditions: Application in Thrombogenicity Testing of Different Materials for Vascular Applications. Int. J. Biomater. 2012, 2012. https://doi.org/10.1155/2012/673163.

(112) Lewis, J. L.; Lew, W. D.; Engebretsen, L.; Hunter, R. E.; Kowalczyk, C. Factors Affecting Graft Force in Surgical Reconstruction of the Anterior Cruciate Ligament. J. Orthop. Res. 1990, 8, 514-521. https://doi.org/10.1002/jor.1100080407.

(113) Poulsson, A. H. C.; Mitchell, S. A.; Davidson, M. R.; Johnstone, A. J.; Emmison, N.; Bradley, R. H. Attachment of Human Primary Osteoblast Cells to Modified Polyethylene Surfaces. Langmuir 2009, 25 (6), 3718-3727. https://doi.org/10.1021/la801820s.

(114) Park, J. H.; Han, C. M.; Lee, E. J.; Kim, H. W. Preparation of Highly Monodispersed PorousChanneled Poly(Caprolactone) Microspheres by a Microfluidic System. Mater. Lett. 2016, 181, 92-98. https://doi.org/10.1016/j.matlet.2016.06.020.

(115) Gerhardt, L.-C.; Boccaccini, A. R. Bioactive Glass and Glass-Ceramic Scaffolds for Bone Tissue Engineering. Materials (Basel). 2010, 3 (7), 3867-3910. https://doi.org/10.3390/ma3073867.

(116) Sivashanmugam, A.; Arun Kumar, R.; Vishnu Priya, M.; Nair, S. V.; Jayakumar, R. An Overview of Injectable Polymeric Hydrogels for Tissue Engineering. Eur. Polym. J. 2015, 72, 543-565. https://doi.org/10.1016/j.eurpolymj.2015.05.014.

(117) Yom-Tov, O.; Neufeld, L.; Seliktar, D.; Bianco-Peled, H. A Novel Design of Injectable Porous Hydrogels with in Situ Pore Formation. Acta Biomater. 2014, 10 (10), 4236-4246. https://doi.org/10.1016/j.actbio.2014.07.006.

(118) Zhao, F.; Grayson, W. L.; Ma, T.; Bunnell, B.; Lu, W. W. Effects of Hydroxyapatite in 3-D ChitosanGelatin Polymer Network on Human Mesenchymal Stem Cell Construct Development. Biomaterials 2006, 27 (9), 1859-1867. https://doi.org/10.1016/j.biomaterials.2005.09.031.

(119) Zhang, Q.; Yan, S.-Q.; Li, M.-Z. Porous Materials Based on Bombyx Mori Silk Fibroin. J. Fiber Bioeng. Informatics 2010, 3 (1), 1-8. https://doi.org/10.3993/jfbi06201001.

(120) Minagawa, T.; Okamura, Y.; Shigemasa, Y.; Minami, S.; Okamoto, Y. Effects of Molecular Weight and Deacetylation Degree of Chitin/Chitosan on Wound Healing. Carbohydr. Polym. 2007, 67 (4), 640-644. https://doi.org/10.1016/j.carbpol.2006.07.007.

(121) Obara, K.; Ishihara, M.; Ishizuka, T.; Fujita, M.; Ozeki, Y.; Maehara, T.; Saito, Y.; Yura, H.; Matsui, T.; Hattori, H.; Kikuchi, M.; Kurita, A. Photocrosslinkable Chitosan Hydrogel Containing Fibroblast Growth Factor-2 Stimulates Wound Healing in Healing-Impaired Db/Db Mice. Biomaterials 2003, 24 (20), 3437-3444. https://doi.org/10.1016/S0142-9612(03)00220-5.

(122) Vaquette, C.; Kahn, C.; Frochot, C.; Nouvel, C.; Six, J.-L.; De Isla, N.; Luo, L.-H.; Cooper-White, J.; Rahouadj, R.; Wang, X. Aligned Poly(L-Lactic-Co-e-Caprolactone) Electrospun Microfibers and Knitted Structure: A Novel Composite Scaffold for Ligament Tissue Engineering. J. Biomed. Mater. Res. A 2010, 94 (4), 
1270-1282. https://doi.org/10.1002/jbm.a.32801.

(123) Vaish. 基因的改变NIH Public Access. Bone 2012, 23 (1), 1-7. https://doi.org/10.1038/jid.2014.371.

(124) Day, R. M. Bioactive Glass Stimulates the Secretion of Angiogenic Growth Factors and Angiogenesis in Vitro. Tissue Eng. 2005, 11 (5), 768-777. https://doi.org/10.1089/ten.2005.11.768.

(125) Oréfice, R.; Hench, L.; Brennan, A. Evaluation of the Interactions between Collagen and the Surface of a Bioactive Glass during in Vitro Test. J. Biomed. Mater. Res. A 2009, 90 (1), 114-120. https://doi.org/10.1002/jbm.a.32080.

(126) Wang, Y.; Yang, C.; Chen, X.; Zhao, N. Development and Characterization of Novel Biomimetic Composite Scaffolds Based on Bioglass-Collagen-Hyaluronic Acid-Phosphatidylserine for Tissue Engineering Applications. Macromol. Mater. Eng. 2006, 291, 254-262. https://doi.org/10.1002/mame.200500381.

(127) Fu, Q.; Rahaman, M. N.; Fu, H.; Liu, X. Silicate, Borosilicate, and Borate Bioactive Glass Scaffolds with Controllable Degradation Rate for Bone Tissue Engineering Applications. I. Preparation and in Vitro Degradation. J. Biomed. Mater. Res. Part A 2010, 95A, 164-171. https://doi.org/10.1002/jbm.a.32824.

(128) Valerio, P.; Pereira, M. M.; Goes, A. M.; Leite, M. F. The Effect of Ionic Products from Bioactive Glass Dissolution on Osteoblast Proliferation and Collagen Production. Biomaterials 2004, 25, 2941-2948. https://doi.org/10.1016/j.biomaterials.2003.09.086.

(129) Rahaman, M. N.; Day, D. E.; Sonny Bal, B.; Fu, Q.; Jung, S. B.; Bonewald, L. F.; Tomsia, A. P. Bioactive Glass in Tissue Engineering. Acta Biomater. 2011, 7 (6), 2355-2373. https://doi.org/10.1016/j.actbio.2011.03.016.

(130) Liu, H.; Fan, H.; Wang, Y.; Toh, S. L.; Goh, J. C. H. The Interaction between a Combined Knitted Silk Scaffold and Microporous Silk Sponge with Human Mesenchymal Stem Cells for Ligament Tissue Engineering. Biomaterials 2008, 29 (6), 662-674. https://doi.org/10.1016/j.biomaterials.2007.10.035.

(131) Daniels, a U.; Chang, M. K.; Andriano, K. P. Mechanical Properties of Biodegradable Polymers and Composites Proposed for Internal Fixation of Bone. J Appl Biomater 1990, 1, 57-78. https://doi.org/10.1002/jab.770010109.

(132) Rigal, J.; Thelen, T.; Angelliaume, a.; Pontailler, J.-R.; Lefevre, Y. A New Procedure for Fractures of the Medial Epicondyle in Children: Mitek ${ }^{\circledR}$ Bone Suture Anchor. Orthop. Traumatol. Surg. Res. 2016, 102 (1), 117-120. https://doi.org/10.1016/j.otsr.2015.09.035.

(133) Anindyajati, A.; Boughton, P.; Ruys, A. J. Mechanical and Cytocompatibility Evaluation of UHMWPE/PCL/Bioglass ${ }^{\circledR}$ Fibrous Composite for Acetabular Labrum Implant. Materials (Basel). 2019, 16 (6). https://doi.org/10.3390/ma12060916.

(134) Laflamme, M.; Lamontagne, J.; Guidoin, R. * - Anterior Cruciate Ligament Prostheses Using Biotextiles; Elsevier Ltd., 2015. https://doi.org/10.1016/B978-1-78242-017-0.00007-6.

(135) Li, M.; Mondrinos, M. J.; Chen, X.; Gandhi, M. R.; Ko, F. K.; Lelkes, P. I. Elastin Blends for Tissue Engineering Scaffolds. J. Biomed. Mater. Res. Part A 2006, 79 (4), 963-973. https://doi.org/10.1002/jbm.a.

(136) Bach, J. S.; Detrez, F.; Cherkaoui, M.; Cantournet, S.; Ku, D. N.; Corté, L. Hydrogel Fibers for ACL Prosthesis: Design and Mechanical Evaluation of PVA and PVA/UHMWPE Fiber Constructs. J. Biomech. 2013, 
46 (8), 1463-1470. https://doi.org/10.1016/j.jbiomech.2013.02.020.

(137) Zhang, P.; Han, F.; Chen, T.; Wu, Z.; Chen, S. “Swiss Roll”-Like Bioactive Hybrid Scaffolds for Promoting Bone Tissue Ingrowth and Tendon-Bone Healing After Anterior Cruciate Ligament Reconstruction. Biomater. Sci. 2020, 8 (3), 871-883. https://doi.org/10.1039/c9bm01703h.

(138) Tong, S. Y.; Wang, Z.; Lim, P. N.; Wang, W.; Thian, E. S. Uniformly-Dispersed NanohydroxapatiteReinforced Poly( $\varepsilon$-Caprolactone) Composite Films for Tendon Tissue Engineering Application. Mater. Sci. Eng. C 2017, 70, 1149-1155. https://doi.org/10.1016/j.msec.2016.03.051.

(139) Zhang, Q.; Li, C.; Luan, J.; Guan, G.; Lin, J.; Wang, F.; Wang, L. Polycaprolactone / Ultra-High Molecular Weight Polyethylene Partially Absorbable Suture with Improved Mechanical Performances for Tendon and Ligament Repair. 2020. https://doi.org/10.1177/0040517520912478.

(140) Schmidt, C. C.; Georgescu, H. I.; Kwoh, C. K.; Blomstrom, G. L.; Engle, C. P.; Larkin, L. A.; Evans, C. H.; Woo, S. L. Effect of Growth Factors on the Proliferation of Fibroblasts from the Medial Collateral and Anterior Cruciate Ligaments. J. Orthop. Res. 1995, 13 (2), 184-190. https://doi.org/10.1002/jor.1100130206.

(141) T., M.; Y., W.; G.A.C., M. The Roles of Growth Factors in Tendon and Ligament Healing. Sport. Med. 2003, 33 (5), 381-394. https://doi.org/10.2165/00007256-200333050-00004.

(142) Pierce, G. F.; Mustoe, T. A.; Lingelbach, J.; Masakowski, V. R.; Griffin, G. L.; Senior, R. M.; Deuel, T. F. Platelet-Derived Growth Factor and Transforming Growth Factor- $\beta$ Enhance Tissue Repair Activities by Unique Mechanisms. J. Cell Biol. 1989, 109 (1), 429-440. https://doi.org/10.1083/jcb.109.1.429.

(143) Jones, J. I. Insulin-like Growth Factors and Their Binding Proteins: Biological Actions. Endocr. Rev. 2004, 16 (1), 3-34. https://doi.org/10.1210/er.16.1.3.

(144) Marui, T.; Niyibizi, C.; Georgescu, H. I.; Cao, M.; Kavalkovich, K. W.; Levine, R. E.; Woo, S. L. Y. Effect of Growth Factors on Matrix Synthesis by Ligament Fibroblasts. J. Orthop. Res. 1997, 15 (1), 18-23. https://doi.org/10.1002/jor.1100150104.

(145) Nau, T.; Teuschl, A. Regeneration of the Anterior Cruciate Ligament: Current Strategies in Tissue Engineering. World J. Orthop. 2015, 6 (1), 127-136. https://doi.org/10.5312/wjo.v6.i1.127.

(146) Hirukawa, M.; Katayama, S.; Sato, T.; Yamada, M.; Kageyama, S.; Unno, H.; Suzuki, Y.; Miura, Y.; Shiratsuchi, E.; Hasegawa, M.; Miyamoto, K.; Horiuchi, T. Development of Tissue-Engineered Ligaments: Elastin Promotes Regeneration of the Rabbit Medial Collateral Ligament. Artif. Organs 2018, 42 (6), E102-E113. https://doi.org/10.1111/aor.13066.

(147) Leong, N. L.; Arshi, A.; Kabir, N.; Nazemi, A.; Petrigliano, F. A.; Wu, B. M.; McAllister, D. R. In Vitro and in Vivo Evaluation of Heparin Mediated Growth Factor Release from Tissue-Engineered Constructs for Anterior Cruciate Ligament Reconstruction. J. Orthop. Res. 2015, 33 (2), 229-236. https://doi.org/10.1002/jor.22757.

(148) Cheng, M.; Johnson, V. M.; Murray, M. M. Effects of Age and Platelet-Rich Plasma on ACL Cell Viability and Collagen Gene Expression. J. Orthop. Res. 2012, 30 (1), 79-85. https://doi.org/10.1002/jor.21496.

(149) Ai, C.; Sheng, D.; Chen, J.; Cai, J.; Wang, S.; Jiang, J.; Chen, S. Surface Modification of Vascular Endothelial Growth Factor-Loaded Silk Fibroin to Improve Biological Performance of Ultra-High-Molecular- 
Weight Polyethylene via Promoting Angiogenesis. Int. J. Nanomedicine 2017, 12, 7737-7750. https://doi.org/10.2147/IJN.S148845.

(150) Stegen, S.; Carmeliet, G. Vascular Endothelial Growth Factor and Bone-Vascular Interactions; Elsevier Inc., 2020. https://doi.org/10.1016/b978-0-12-814841-9.00046-4. 